\title{
Neogene structures overprinting Palaeozoic thrust systems in the Andean Precordillera at $30^{\circ} \mathrm{S}$ latitude
}

J. Alvarez-Marron ${ }^{1}$, R. Rodriguez-Fernandez ${ }^{2}$, N. Heredia ${ }^{2}$, P. Busquets ${ }^{3}$, F. Colombo ${ }^{3}$, and D. Brown ${ }^{1}$

1. Institute of Earth Sciences, “J. Almera”, CSIC,

c/ Lluis Sole i Sabaris s/n, 08028 Barcelona, Spain

2. Instituto Geológico y Minero de España, c/ La Calera 1, Tres Cantos, E-28760 Madrid, Spain.

3. Facultad de Geología,University of Barcelona, c/ Marti i Franques s/n, E-08028 Barcelona, Spain.

Corresponding author: J. Alvarez-Marron

Institute of Earth Sciences, "J. Almera”, CSIC,

c/ Lluis Sole i Sabaris s/n, 08028 Barcelona, Spain

T1., 34 - 34095410

Fax., 34 - 34110012

E-mail, jalvarez@ija.csic.es

\begin{abstract}
Field studies along a $30^{\circ} \mathrm{S}$ latitude transect of the Precordillera in NW Argentina indicate that Neogene to recent deformation caused high-angle faulting that uplifted and breached a Palaeozoic Everging thrust stack. Palaeozoic structures outcrop in the higher linear ranges, and intramontane Neogene basins occur in the intervening valleys.

The Palaeozoic rocks include three tectonic units with contrasting structural styles and differences in stratigraphy. The Western Allochthon includes clastic Ordovician rocks metamorphosed to lower greenschist facies and folded by large-scale asymmetric, E-verging folds with a well-developed axial planar cleavage. This unit overthrusts a Siluro-Devonian flysch-type succession of the Central Imbricate thrust system and associated fault propagation folds in which the thrusts merge into a basal thrust beneath Ordovician carbonates. Middle to Late Carboniferous sediments unconformably overlie structures of this imbricate system. In the Frontal Unit minor thrust faults are interpreted to explain the low angle unconformity wthin Paleozoic rocks.

Neogene deformation causes only minor overprint of the Palaeozoic structure, and large scale folding in the Frontal Unit appears to be mostly of Neogene age. The new data indicates that Neogene intracontinental shortening may be smaller than previously proposed, providing new perspectives to the present orogenic architecture along this Andean section.
\end{abstract}

Keywords: Argentine Precordillera, Andes, Paleozoic, Neogene, structure. 
The segment of the Andean orogen between $29-33^{\circ} \mathrm{S}$ latitude is divided into several geological provinces that form N-S trending belts (Fig. 1) (Ramos 1988). This segment records geological processes interpreted to be associated with the evolution of an active continental margin since the Early Palaeozoic (Ramos 1988; Rapela et al. 1998). In te foothills, the Precordillera of NW Argentina has played a key role in a number of tectonic interpretations, with implications for the whole orogenic section (Allmendinger et al. 1990; Ramos 1988, 2002; Dalziel 1997). However, fundamental data for the understanding of the structural evolution of the Precordillera and the deformation processes involved in the construction of this part of the orogen remain controversial or insufficiently constrained. For example, the existence of preAndean deformation within the Palaeozoic sedimentary strata in the Precordillera has been largely known (e.g. Furque 1979; Gosen 1997), yet there is no general agreement on the number of Paleozoic deformation events, their timing or their distribution. Consequently, contrasting interpretations of the Palaeozoic tectonic framework remain, because aspects such as the structural geometries, vergence and kinematics are not well known. In addition, a few studies have integrated structural data of both Andean and pre-Andean structures. Discriminating between Andean and pre-Andean structures and their interference is fundamental for deciphering the structural architecture that resulted from different deformation events, and to stablish the tectonic evolution of the Precordillera.

Along the deeply incised valley of the Jáchal River, which runs perpendicular to the strike of the Andean foothills, an almost continuous, $50 \mathrm{~km}$ long section of the Precordillera is very well exposed (Fig. 2). This paper presents a field based structural study of the area, aided by 1:50,000 scale aerial photographs, TM satellite images and mostly 1:250,000 scale, geological maps of the Argentinian Geological Survey (SEGEMAR) (Furque 1979; Cardo, in press; Furque et al. 1998). The study focused on a structural analysis of both the Andean and pre-Andean deformations in order to establish their geometries and to discriminate the characteristics of each deformation event. The integrated geological cross-section along the Jáchal River area provides a new view of the structure of the region, and new data for interpreting the tectonic evolution along this section of the Andean external zone.

\section{Geological Framework}

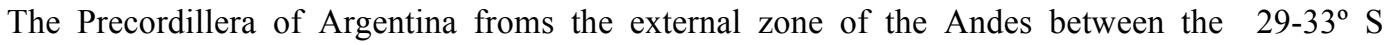
(Ramos 1988). It overlies a subhorizontal portion of the subducted Nazca plate (Cahill \& Isacks 1992), and has lacked major magmatism since $\sim 10 \mathrm{Ma}$ (Kay et al. 1988). The Precordillera forms an elongated 400 $\mathrm{km}$ long by $80 \mathrm{~km}$ wide belt of mostly Palaeozoic rocks that reaches maximum elevations of $4000 \mathrm{~m}$ (Fig. 1). It is bound in the west and east by active Cenozoic basins. The Iglesia-Calingasta Basin covers the structural boundary with the Cordillera Frontal in the west, and in the east, the Bermejo Basin is part of a larger foreland basin that is disrupted by large Proterozoic basement uplifts (Sierras Pampeanas). Most previous structural studies of the Precordillera focused on two E-W sections along crosscutting river valleys that provide the best access and exposure (Gosen 1992, 1997; Allmendinger et al. 1990). The northernmost of these valleys is that of the Jáchal River near $30^{\circ} \mathrm{S}$. This study is focused on this northern section of the Precordillera, between the towns of Rodeo and Huaco (Fig. 2).

Previous studies in this region interpreted the Andean structure as a set of Neogene, emergent thrust faults that carry previously deformed Palaeozoic and younger cover rocks (Allmendinger et al. 1990; 
Jordan et al. 1993; Gosen 1997). Neogene thrust related shortening and development of syntectonic intramontane basins have developed during the last $18 \mathrm{My}$, simultaneous with the process of slab shallowing (Jordan et al. 1993, Ramos et al. 2002). The Neogene thrusts have been interpreted to ramp upwards from a deep decollement at $\geq 15 \mathrm{~km}$ and to have caused $95 \mathrm{~km}$ of shortening (Allmendinger et al. 1990). Large thrust faults underwent simultaneous motion, and local out of sequence thrusting has been documented (Jordan et al. 1993). The syntectonic basins are filled by continental facies Neogene sediments with large lateral lithological and thickness variations (Fig. 2). For instance, the Iglesia Basin near Rodeo includes up to $3.5 \mathrm{~km}$ of dominantly fine-grained lacustrine and fluvial, upper Miocene to Pliocene sediments (Beer et al. 1990). The intramontane Tranca basin comprises less than $600 \mathrm{~m}$ of dominantly red and brown coloured conglomerates (Jordan et al. 1993). The Bermejo foreland basin contains more than $5000 \mathrm{~m}$ of Tertiary continental sediment in a well drilled near Huaco (Zapata \& Allmendinger 1996a). The Tertiary sediments of the Bermejo Foreland basin are deformed in the Huaco area, east of the area considered here, by hinterland-verging structures related to west directed basement involved thrust faults (Zapata \& Allmendinger 1996a). These structures started to form by $2.7 \mathrm{Ma}$ and are still active (Zapata \& Allmendinger 1996a).

The oldest rocks within the Jáchal River area of the Precordillera are Early Palaeozoic sediments that are unconformably overlain in the central and eastern regions by Carboniferous sediments (Furque 1979). Locally, Permian continental conglomerates (Furque et al. 1998) and red beds of possible Triassic age are found (Zapata \& Allmendinger 1996a). The Early Palaeozoic stratigraphy varies greatly from E to W (Fig. 2). In the west, a large thickness of siliciclastic and volcanic rocks are attributed to the Ordovician, including a $2 \mathrm{~km}$ wide outcrop of pillow basalts beneath the contact with Iglesia Basin sediments, and a unit with large calcareous olistholiths and mass flow deposits bounds the Ordovician sequences in the east (Furque 1979; Gosen 1997; Astini et al. 1995). In the central part, a large thickness of Siluro-Devonian siliciclastic sediments are underlain by thinner Lower Ordovician carbonates of the San Juan Formation (Furque et al. 1998). Although the boundary between the Silurian and Devonian is not well established, the Devonian series includes a thin-bedded unit with mostly siltstones in the lower part and a thicker bedded unit with sandstones and conglomerates in the upper part (Fig. 2). Furque et al. (1998) described a low angle unconformity beneath Silurian sediments that overlie the Early Ordovician San Juan Formation or younger thin unit of Ordovician clastic sediments. The deformed Siluro-Devonian sediments are unconformably overlain by Carboniferous strata of the Volcan Formation that outcrops to the north of San José de Jáchal (Furque 1979). In the easternmost part of the Jáchal River area, the oldest rocks are the Ordovician carbonates of the San Juan Formation overlain by a thin veneer of Siluro-Devonian rocks (Furque 1979). At one locality thin Upper Cambrian limestones were found concordantly beneath the San Juan Formation (Furque et al. 1998). Palaeozoic deformation in the Jáchal River area has been studied by Gosen (1997), who describes different fold types and vergences that were interpreted to have been influenced by a former escarpment related to a normal fault within the Early Palaeozoic basin. West of the escarpment, Ordovician basin and slope sediments were folded and experience low greenschist facies metamorphism. To the East, the Early Palaeozoic carbonate platform underwent W-verging folding without a clear metamorphic overprint (Gosen 1997). This study proposed a Devonian to pre-Upper Carboniferous 
age for the structures in the East, and argued for a possibly older age (Late Silurian) for the structures in the West.

\section{Structure of the Jáchal River area}

Structural analysis of the Jáchal River area is focused along a $50 \mathrm{~km}$ wide mapped transect from the eastern margin of the Iglesia Basin in the west to the eastern most outcrop of Palaeozoic rocks near Huaco (Fig. 3). Along this transect, a NNE-SSW trending fault system appears to be responsible for the spatial distribution of the Palaeozoic and Cenozoic outcrops which produces a topographic pattern that consists of N-S trending ridges and depressions. The ridges include the outcrops of deformed Palaeozoic strata and the depressions are occupied by Cenozoic sediments within fault-related basins. Large, active, Quaternary alluvial fans appear along most of the ridge slopes and cover previous sediments and structures in topographic lows. In particular, interpreted Neogene fault traces are covered along tens of kilometers in the northern part of the Jáchal Basin (Fig. 3). Tens of meters of the Quaternary alluvial fan stratigraphy is exposed along the sides of the Jáchal River due to the progressive incision of the river.

The composite cross-section along the Jáchal River area illustrates the geometries of the Paleozoic and Neogene-recent structures (Fig. 4). The Palaeozoic deformation resulted in an east-verging thrust stack, and the Neogene to Present deformation resulted in a high-angle fault system breaching through and uplifting the previous Palaeozoic thrust stack, and forming related intramontane basins.

\section{Neogene structures and associated basins}

Along the Jáchal River section of the Precordillera, the sedimentary basins that developed between the outcrops of previously deformed Palaeozoic rocks appear to be related to high-angle faults that form a linked fault system in map view (Fig. 3). The linkage is less apparent in the eastern part of the map. The basins include Neogene continental facies sediments that were deposited synchronous with fault activity since $18 \mathrm{Ma}$ (Jordan et al. 1993). In some basins, older sediments of Permian to Tertiary age have been described (Furque 1979; Jordan et al. 1993). The basins differ in dimensions, sedimentary thickness and facies, and in the distribution of unconformities within the Neogene sequences. Correlations of sedimentary packages and main unconformities from one basin to another are hampered by geographic isolation.

The Neogene fault system comprises several fault sets (Fig. 3). The dominant set consists of NNE striking high-angle faults that in most cases are east directed thrusts (Fig. 4). Although, N-S striking reverse faults and less well developed NW striking faults are also present. The major faults typically display fault gouges that can reach up to several meters wide. Reliable kinematic indicators are rarely developed within the fault gouges especially when the faults cut the soft and unconsolidated Neogene sediments. Where the Neogene faults affect the Palaeozoic rocks, slickensides with gentle SW plunges (less than $40^{\circ}$ ), indicative of oblique displacement have been found. Meter to tens of meters scale structures, such as folds and faults accompany the major faults, and deform the sedimentary sequences within the basins. These minor structures allow interpretations on fault kinematics based on geometrical relationships between linked fault planes and fault related folds (see below). 
In the following sections, the Neogene structures and the relationships between the major faults, associated minor structures, and syntectonic sediments are described in detail, taking examples from several basins.

\section{Structures in the Iglesia Basin}

The Iglesia Basin constitutes the northern part of the c. $150 \mathrm{~km}$ long Iglesia-Calingasta Basin that separates the Precordillera from the Cordillera Frontal (Fig. 1 and 2a). Previous studies in this northern area proposed that the basin includes a Neogene sequence up to $3.5 \mathrm{~km}$ thick, and interpreted the basin as a piggyback basin that developed during the eastward advance of Precordillera thrusts (Beer et al. 1990, Jordan et al. 1993). The Iglesia River deformation zone, which affects the eastern part of the Iglesia Basin, corresponds to the northward prolongation of the El Tigre Fault as shown in Argentinian geological maps (Cardo, in press). The El Tigre Fault is a $\sim 120 \mathrm{~km}$ long active strike-slip fault within the Iglesia-Calingasta basin. Recent deformation along this fault has been dated by right-lateral displacements along 20 to $700 \mathrm{ka}$ old alluvial fan surfaces some $70 \mathrm{~km}$ south of Rodeo, where $1 \mathrm{~mm} /$ year slip rates have been calculated (Siame et al. 1997).

The geometrical characteristics of Neogene structures within the Iglesia Basin are well exposed in a NNE trending, several kilometer wide, deformation zone following the valley of the Iglesia River (Fig. 5). Along the deformation zone Miocene to Pliocene sediments of the basin fill, together with some isolated outcrops of Palaeozoic basement are exposed (Fig. 5a). Major faults are steeply dipping at the surface, with fault planes dipping 80 degrees and more, and may show reverse or normal vertical throws (see sections 1 , 2 and 3 in Fig. 5). Changes in dip direction along-strike are also found. Sediments commonly form steep monoclines near the fault planes, and away from the faults, they either form wide zones of subhorizontal bedding, or very open folds of varied geometries and dimensions. Progressive unconformities are developed within the fault related monoclines and, locally, at the contact with Palaeozoic basement rocks. These geometries indicate that sedimentation was synchronous with fault activity. Folds are non-cylindrical folds on a scale of tens of meters, and

have abrupt lateral terminations (Fig. 5B). In outcrop, minor, meter-scale thrusts and associated fault-propagation folds show $\mathrm{E}$ and $\mathrm{W}$ vergence.

The seismic reflection sections across the Iglesia Basin provide a two dimensional image of the basin structure. The sedimentary fill is very well imaged above the sharp top basement reflection (Fig. $5 \mathrm{C}$ and 6). The sediments are progresively younger as they onlap the basement towards the west. A zone of deformation in the east includes east and west directed faults with an apparent reverse throw and some minor faults with apparent normal throw. In Fig. 6, syntectonic sediments above fault A thicken towards the crest of the fault related anticline. These geometries of double vergence and distribution of sedimentation apparently unrelated (in a two dimensional view) to the faulting are commonly related to strike-slip fault systems (Sylvester 1988). On the basis of the outcrop data and the seismic sections we therefore interpret the large-scale architecture of the deformation zone within this part of the Iglesia Basin as a positive flower structure with Miocene to Pliocene sedimentation synchronous with fault activity (Fig. $5 \mathrm{C}$ and 6). 


\section{Structures in the Tranca and Caracol Basins}

The narrow intramontane Tranca and Caracol basins, south of the Jáchal River include less than 1 $\mathrm{km}$ thick Neogene sedimentary sequences (Fig. 7 and 8). In both, there are high angle faults with a dominant NNE trend, that are slightly oblique to the structures of the Palaeozoic basement. The oldest sediments within the basins are "red beds" that are thought to correspond to the Oligocene or Early Miocene, on the basis of lithological correlations, and are interpreted to predate fault activity (Jordan et al. 1993). In both basins, fault-bound "red coloured" beds are unconformably covered by younger sediments (Fig. 7 and 8), although correlations between the two basins and with the "red beds" described by Jordan et al. (1993) are not clear. The younger sediments have been dated as Miocene (Jordan et al. 1993) and include progressive unconformities and local infill of erosive palaeotopography suggesting syntectonic deposition. Fluvial and alluvial conglomerates dominate within these syntectonic sequences.

In the Tranca basin a dominant W-dipping thrust with two minor E vergent thrusts linked to it, deform three sedimentary packages that are separated by basin wide unconformities (sections $\mathrm{a}, \mathrm{b}$ and $\mathrm{c}$ in Fig. 7). Above the "red coloured" beds, the younger syntectonic sediments onlap onto the Palaeozoic rocks at both margins of the basin, and thicken towards the center. They form broad, open synclines at both sides of the main fault. An upper package of syntectonic sediments drapes over the main fault and covers it towards the south (cross-section $\mathrm{c}$ in Fig. 7). The two minor E vergent thrust planes have progressively shallower dips along strike towards the intersection with the high angle thrust. Geometrical relationships between minor folds associated with these minor thrusts, the orientation of the fault planes and their intersections suggest a left-lateral component of displacement for the high angle thrust.

In the Caracol basin, discontinuous rhomb-shaped outcrops of Palaeozoic basement rocks have faulted and unconformable contacts with surrounding Neogene basin sediments (Fig.s 8). Apart from these outcrops, a large part of the basin is covered by Quaternary alluvial deposits. Fine grained aprons of sediment spread down slope from the eastern Palaeozoic rocks, and in the centre coarser grained conglomerates appear associated with the seasonal Caracol stream. Palaeozoic rocks in the western part of the basin are overthrust onto an asymmetric syncline of "red beds" (sections A and C, Fig. 8), and locally overthrust westwards onto overturned "red beds" of the eastern basin margin (section B, Fig. 8). Here the Palaeozoic stratigraphy and structure is overturned with a thin layer of carbonate rocks thrust over SiluroDevonian clastics.

Faults within the basin have both normal and reverse displacement and subvertical dip (Fig. 4). In the west, the Neogene sediments are folded into a tight upright syncline against the Palaeozoic rocks and show very gentle dips away from the fault. The geometries of the sedimentary sequences, and of the structures along the studied area, lead us to interpret the basin as part of a negative flower structure.

\section{Structures in the Jáchal and Fiscal Basins}

Along most of the Jáchal basin, the Neogene sequences are covered by large Quaternary alluvial fan deposits. Narrow outcrops of Neogene strata are only found in two places. On the eastern margin of the basin starting to the north of the cross-section, a narrow strip of Upper Pliocene sediments progressively covers southwards the Permian, Carboniferous and Ordovician age sediments of the underlying west dipping monocline (Furque et al. 1998). On the western margin of the basin, south of San José de Jáchal, 
the Neogene deposits appear along a narrow asymmetric syncline in fault contact with carbonates of the San Juan Formation (Fig. 9A). This locality includes less than $800 \mathrm{~m}$ of mostly Lower Miocene sediments (Jordan et al. 1993). The Fiscal Fault trends subparallel to the trace of Ordovician sediments with a curved shape in map view. Along most of this curved trace Quaternary sediments appear in the immediate footwall hampering the interpretation of the geometry at depth. In the hangingwall, Ordovician sediments dip $60^{\circ}$ $70^{\circ}$ to the West along the trace of the cross-section in Fig. 4. At the base, a several meter wide fault gouge dips parallel to the hangingwall beds. To the south, hangingwall bedding dips $40^{\circ}-50^{\circ}$ to the Northwest. The Fiscal Fault is a reverse fault that has brought to surface the Ordovician carbonates, placing them on top of Neogene strata of the Fiscal Basin.

Neogene sediments in the Fiscal Basin reach up to $1200 \mathrm{~m}$ thickness (Jordan et al. 1993), although thickness varies laterally due to unconformities. Most of the sequence appears to be folded together with the underlying Palaeozoic deposits into a wide synform (Fig. 9B). Inverted west dipping conglomerates appear under the fault gouge of the Fiscal Fault, indicating the dragging of footwall sediments during faulting. The geometry of the synform at depth is constructed by taking into account sediment thickness and dip angles measured along the Huaco road section. To the East of the Fiscal Basin, the Ordovician carbonates are folded into a large box-shaped anticline. The eastern flank of the fold is subvertical and sediments of the Bermejo Basin appear to the east on a steep, east-dipping unconformable contact. However, south of the cross-section the Ordovician carbonates are thrust onto the Bermejo Basin sediments along a NE trending fault (Fig. 3), the outcropping Neogene sediments of the Fiscal Basin form a west dipping monocline that is unconformably covered by Late Pliocene conglomerates (Jordan et al. 1993). This structure was also mapped in detail by Zapata \& Allmendinger (1996a). These Late Pliocene deposits wrap around into a south-plunging periclinal structure indicating that sedimentation was synchronous with the tilting associated with bedding-parallel slip of the underlying homoclinal sequence. Differential bedding parallel slip on a steeply dipping multilayer below an unconformity produces folding in the sediments above the unconformity (Alonso 1989). This deformation could be related to activity of the Fiscal fault in the last 2.7 Ma (Zapata \& Allmendinger 1996a).

\section{Palaeozoic Thrust systems}

Within the Palaeozoic outcrops of the Jáchal River area, only one pre-Neogene deformation event has been recognized (Fig.s 3 and 4). The Palaeozoic structure consists of an east vergent thrust stack that includes three units with varied stratigraphy and structural style (Fig. 3 and 4). From West to East, the three tectonic units are; 1) the Western allochthon which deforms a large thickness of Ordovician age, mostly siliciclastic rocks, 2) a Central Imbricate thrust system that includes a large thickness of siliciclastic SiluroDevonian rocks, and 3) a Frontal Unit including a thinner sequence of Ordovician and Silurian rocks. The Central Imbricate thrust system and the Frontal Unit include Ordovician carbonates of the San Juan Formation (oldest rocks outcropping in this section of the Precordillera) at the base of thrust sheets. In the central part of the Jáchal River area thrusts and folds deforming Ordovician to Devonian rocks are unconformably overlain by Middle to Late Carboniferous rocks of the Volcan Formation (Furque, 1979; Furque et al., 1998), placing an upper limit on the age of the Palaeozoic deformation (Fig. 10A and B). 


\section{The Western Allochthon}

The Western Allochthon is an east directed thrust stack that includes Ordovician metasedimentary rocks that underwent lower greenschist facies metamorphism (Gosen 1997). The whole series of sedimentary and volcanic rocks are included in the Upper Ordovician - Early Caradocian Yerba Loca Formation (Furque 1979). There are outstanding lithological differences along the section that are grouped into four units separated by thrusts in the lithotectonic column (Fig. 2C).

Thinner bedded, finer grained sericitic siltstones and marls within well stratified sandstone beds are frequent to the east (Los Tuneles area, Unit 3 in Fig. 2C), while thicker bedded, coarser grained sediments and conglomerates that commonly include sills and lenticular shaped bodies of basic and ultrabasic rocks appear in the west (Cuesta del Viento area, Unit 4 in Fig. 2C). Volcanic rocks appear in the west interbedded within the coarser grained sediments. These sediments are organized in shallowing upwards sequences that in some cases are topped with a layer of columnar jointed basalts. A $200 \mathrm{~m}$ wide continuous outcrop of pillow basalts occur along the road cut at Cuesta del Viento. These pillow basalts are in fault contact at the western edge of the allochthon, and are unconformably covered by Tertiary sediments of the Iglesia Basin (Fig. 4 and 11A). Chaotic sediments including mass flow deposits and large calcareous olistoliths within a siliciclastic matrix are included into two, thin thrust sheets that bounds the allochthon to the east along the road section (Units 1 and 2 in Fig. 2C). These have been previously interpreted as forming a sedimentary mélange (Gosen 1997).

The Western Allochthon is folded by a km-scale antiform-synform fold pair that possibly developed during the latest stages of emplacement, and which has been deformed by later Neogene faulting (Fig. 4). The internal structure of the Western Allochthon is best displayed at Cuesta del Viento and Sierra de los Tuneles along the Jáchal River road cut (Fig. 4 and 11). At Cuesta del Viento a 5-km scale antiform is cored by a fault. Along its western flank a large outcrop ( $>200 \mathrm{~m}$ along the road section) of pillow basalts dip moderately westwards (Fig. 11A). The eastern flank is marked by a narrow, fault bounded zone of steeply E-dipping bedding and east-dipping cleavage. The asymmetric Z-shaped minor folds in this part of the section have been previously interpreted as west vergent structures because of the attitude of the cleavage (Ramos 1988; Gosen 1997). Way up criteria, such as small scale gradded bedding is not conclusive in this area, but the $\mathrm{Z}$ shape of the minor folds, the overall fining eastward of the bedding, and other geometric criteria such as the normal position of the stratigraphy across the remaining section, suggest that these folds can be better interpreted as downward -facing minor folds on the eastern flank of a larger antiform. This antiform would fold the large normal limb of an east vergent structure (see below). The remaining Cuesta del Viento outcrop contains upright folds with a near vertical axial planar cleavage (S1). S1 shows varied dips locally due to cleavage refraction caused by the presence of mafic sills and lenticular shaped bodies of basic and ultrabasic rocks interstratified within less competent rocks (stereoplot in Fig. 11A). Locally, a weakly developed crenulation cleavage (S2) has been found near minor faults. The three thrusts that cut through the allochthon in this section are interpreted as Palaeozoic. They are not seen to cut through younger sediments (Fig. 3).

At Sierra de los Tuneles, the frontal part of the allochthon, consists of an east vergent antiform with a wide normal limb and an overturned narrow frontal limb (Unit 3 in Fig. 11B). The normal limb 
includes east-vergent thrusts and m-scale, minor asymmetric folds with a strong axial planar cleavage. Locally, the cleavage is deformed by centimetre scale shallowly dipping kink bands. A weak crenulation cleavage is developed locally. The folds in the normal limb tighten towards the frontal part of the allochthon, where the overturned limb is cut by the west-dipping basal thrust. The basal thrust overrides the mélange that constitutes the sole of the Western Allochthon (Units 1 and 2 in Fig. 11B). Along the road cut, the mélange consists of two units that are laterally discontinuous. A duplex structure, which includes mostly thin bedded limestones deformed by non-cylindrical tight folds and thrusts (Unit 2), overrides a series of syntectonic mass flow deposits that display widespread slumping, and includes polymictic conglomerates with well rounded quartzitic clasts (Unit 1). These mass flow deposits are deformed by mscale upright folds and a weakly developed cleavage within a wide synformal structure. This synform is in fault contact with Cenozoic sediments of the Caracol Basin in the road section.

The structural relationship between the Western Allochthon and the Central Imbricate thrust system to the east is seen near the area called Puerto Divisadero (Fig. 10A and B). Here Ordovician sandstones and cherts intruded by mafic bodies are thrust onto a sequence that include common carbonate beds, and that display a shear zone at the base. The shear zone is more than $1 \mathrm{~km}$ wide, and is defined by a west dipping dominant foliation including bands with $\mathrm{cm}$-scale sheath folds. The majority of plunge values indicates top to the ESE for the thrusting direction in the present position (Fig. 10C). However, some modification of the original orientations by superposed Neogene faulting cannot be discounted. Immediately beneath the shear zone, east verging folds and thrusts without cleavage deform Silurian to Devonian clastic deposits of the Central Imbricate thrust system.

\section{The Central Imbricate thrust system}

A large, continuous, outcrop of Silurian to Devonian clastic deposits exposed between the Caracol Valley and San José de Jáchal is deformed by a system of East directed imbricate thrusts and related fault propagation folds (Fig. 4). The imbricate thrusts are interpreted to merge into a sole thrust located at the base of a thin layer of Ordovician age carbonates of the San Juan Formation. In the mapped area, the Early Ordovician carbonates of the San Juan Formation are only seen in the eastern edge of the Central Imbricate thrust system (Fig. 9 A).

Folding at different scales is pervasive within the Central Imbricate thrust System. The upper part of the Devonian series occupies the core of the larger synclines found to the south of the Jáchal river (Fig. 3). Towards the eastern part of the cross-section, well exposed, $\mathrm{km}$-scale fault propagation folds are found. In contrast, km-scale folds are less common towards the west (Fig. 4, segment B). The variations of fold size appear to be controlled by differences in bedding thickness within the multilayer, and also by the existence of small-scale thrusting. Most folds in outcrop have a fault propagation fold geometry that varies from common chevron-type with less that $90^{\circ}$ degree interlimb angle to more open cylindrical folds. Locally, fault-bend folds with a box-shaped geometry are also found in relation to hangingwall thrust ramps.

The imbricate thrust system is breached by a later Neogene high-angle fault that juxtaposed two pieces of it (F4 in Fig. 4). To the East of the breaching fault the original position of Palaeozoic structures seems better preserved, allowing more confident interpretations of the structure at depth. Two major 
thrusts can be distinguished by the existence of two bands of Ordovician carbonates mapped to the south of the transect studied here (Furque et al. 1998). These thrusts are interpreted to merge into the basal thrust. Geometrical constraints during cross-section construction indicate that the basal detachment may flatten in this part of the section at a depth no greater than $3 \mathrm{~km}$. To the west of the breaching fault, dominantly thinbedded clastic sediments are deformed by widespread overturned folds and thrusts (Fig. 4, segment B). Back-rotation of the original folds and thrusts, in places taking the limbs to an overturned position, are interpreted to be an effect of Palaeozoic forward imbrication and superposed Neogene deformation (Fig. 4). However, Neogene folds or cross folding effects may have occurred that are difficult to distinguish within this thinly bedded sequence. The lithology within this part of the imbricate resembles that of the Silurian and lower part of the Devonian. Outcrops of the basal Ordovician carbonates and the basal thrust are lacking in this western piece of the imbricate, and the interpretation of the structure at depth is not well constrained. Sporadic outcrops of carbonates along the eastern margin of the Caracol Basin may correspond to the San Juan Formation that has been brought up to the surface by Neogene faulting. However, we favour the interpretation of these carbonates as pieces of the tectonic unit at the sole of the Western Allochthon (Fig. 8).

Structural relationships between the Central Imbricate thrust system and the Frontal Unit are obscured by the Cenozoic deposits along the Jachal Basin, and are not resolved with the available data. There are marked differences between the Palaeozoic stratigraphic sequence present in the Central Imbricate thrust system and that within the Frontal Unit (Fig. 2 C). These differences may argue for a possible large displacement across the frontal thrust of the Central Imbricate thrust system (see below). However, they may be also due to large displacements along Neogene Faults.

\section{The Frontal Unit}

The Frontal Unit includes the easternmost outcrops of Palaeozoic sediments in the Jáchal River area. These consist of two bands of thick Ordovician carbonates that are well exposed along the Huaco River section (Figs. 3 and 4). Carboniferous deposits of the Volcan Formation (Furque et al. 1998) appear in most places directly above the carbonates along a low angle unconformity. Thin Silurian and Devonian clastic sediments are found only in a narrow strip along the eastern margin of the Fiscal Basin south of the section.

The deformation style in the Frontal Unit is markedly different from that of the Palaeozoic thrust units described above. Carboniferous sediments and Neogene deposits of the Fiscal Basin are folded together with underlying Ordovician rocks, indicating that Palaeozoic deformation was probably minor within this unit. However, the low angle base Carboniferous unconformity in the eastern flank of the Fiscal Basin indicates the occurrence of some deformation of underlying beds prior to deposition of Carboniferous sediments. This deformation could have been accomplished by formation of a low amplitude thrust cored anticline. In this scenario, the minor thrust seen at the core of the frontal box-shaped anticline in Fig. 4 is interpreted as corresponding to the Palaeozoic thrust system that merges into a basal decollement beneath the Ordovician carbonates. This basal decollement would continue at the base of the Ordovician carbonates beneath the Fiscal and Jachal basins to join the basal thrust beneath the Central Imbricate thrust system (Fig. 12). We interpret the Palaeozoic thrust front as a protothrust, in which slip 
along the basal thrust dies out into a low amplitude thrust-cored anticline at the deformation front of the Palaeozoic thrust stack. The Fiscal Fault is interpreted to have breached through a flat lying part of the Palaeozoic thrust unit. The km-scale folds that show a box-like geometry along the cross-section could be the result of superposed folding and amplification associated with the two high angle Neogene faults that breach through the Frontal Unit (Fig. 4).

\section{Discussion}

The outcropping geology along the Jáchal River area includes a sedimentary record from the Early Ordovician to the present, with a large gap during Jurassic to Early Tertiary (Furque et al. 1998; Jordan et al. 1993). The Early Palaeozoic sequences are mostly shallow marine with deeper clastic sequences in the western part (Astini et al. 1995; Keller 1999), and unconformably covered by Carboniferous continental to shallow marine clastic sequences in the East (Furque et al. 1998). The Cenozoic sequences are mostly Neogene to present continental sediments (Beer et al. 1990, Jordan et al. 1993). Our structural analysis indicates that sedimentation records two episodes of contractional deformation, one in the Palaeozoic and the other in the Neogene to Present. The earlier resulted in large amounts of shortening and the latest included tranpressive displacements that mildly overprint previous structures. The combined effects of early contraction and superposed transpression impose many uncertainties on the interpretations of the structure and in establishing $\mathrm{E}$ to $\mathrm{W}$ structural and stratigraphic correlations along a single transect. Uncertainties were encountered during the construction of the cross-section along the Jáchal River area, mostly in the interpretation at depth of both the Palaeozoic and Neogene structures. Section balancing geometrical constraints are not applicable because "plane-strain" cannot be assumed. This also hampers the calculations of the amount of shortening. In addition, the lack of pre-Neogene undeformed reference horizons hinders calculations of displacements along Neogene faults. Structural studies along parallel sections to the $\mathrm{N}$ and $\mathrm{S}$ are necessary to reduce these uncertainties.

\section{Palaeozoic deformation}

The present architecture of the Palaeozoic structures along the Jáchal River section indicates that Palaeozoic shortening was accomplished by east directed thrusting and folding. The Palaeozoic structures are interpreted to form a thrust wedge made up of three units with structural styles that indicate development of shallower deformation conditions from west to east (Fig. 12). The deeper deformation conditions occurred in the Western Allochthon, the Central Imbricate includes structural styles typical of upper crustal foreland thrust and fold belts, and the Frontal Unit is interpreted to register minor Palaeozoic deformation at the front of the thrust wedge. Structural relationships between these three units of the thrust wedge are masked by later, Neogene sedimentation and breaching faults. Sharp structural and stratigraphic differences between the thrust units are accentuated by Neogene-age oblique juxtaposition of pieces of the thrust wedge that originally were laterally and vertically separated.

The Western Allochthon structure is unlikely to be of Neogene age, given that Neogene deformation conditions were much shallower, as indicated by the associated continental facies sedimentation (Beer et al. 1990; Jordan et al. 1993). The allochthon, at the rear of the Palaeozoic thrust wedge, includes internally strained and slightly metamorphosed sediments that are different from the sediments in the other units (Astini 
et al. 1995; Gosen 1997). The stratigraphic differences are thought to be related to Ordovician rifting at the western edge of a carbonate platform (see Keller 1999 for a review), and structural differences are due to Palaeozoic thrusting and telescoping combined with Neogene faulting. The sediments within the thin tectonic units at the sole of this allochthon (the so called mélange by Gosen 1997) contain rocks with a variety of ages including Early Cambrian and Early Ordovician carbonates, Llanvirnian shales, and ages as young as Caradoc have been proposed (Keller 1999). The simplest interpretation of the duplex structure in carbonates at Los Tuneles (Unit 2) is that they represent off scraped material from the underlying continental margin, as the Western Allochthon was thrust eastwards. Previous interpretations considered them as part of a sedimentary mélange related to the western slope facies of a Cambro-Ordovician passive continental margin (Gonzalez Bonorino \& Gonzalez Bonorino 1991), as related to extensional faulting in the western margin of the continental platform (Gosen 1997), or as belonging to the continental rise (Keller 1999). In our interpretation, some off scraped carbonate material (Unit 2) was later attached to syntectonic deposits (mass flow deposits, Unit 1) and both ended underplated to the toe of the Western Allochthon, forming a tectonic mélange.

The remaining central and frontal units of the thrust wedge show structural styles developed at shallower crustal conditions than those in the Western Allochthon (Fig. 12). Thin-skinned deformation, with thrust imbrication and related folding above a detachment at the base of Ordovician carbonates, appears to have resulted in significant shortening within the Central Imbricate prior to deposition of Carboniferous sediments, in contrast with that of the Frontal Unit. This eastern part of the section exhibits mostly Neogene deformation (Zapata \& Allmendinger, 1996b). However, some Palaeozoic shortening occurred as evidenced by the low angle unconformity beneath Carboniferous sediments. To explain this, we interpret the Frontal Unit as a protothrust at the front of the Palaeozoic thrust wedge, developed ahead of an emergent thrust system in the Central Imbricate.

The precise age of Palaeozoic shortening along the Jáchal River area is not well constrained. The existence of pre-Carboniferous contraction along this area was first demonstrated by Furque (1979), based on mapped and stratigraphic evidence. Ramos (1986) proposed that intense deformation in the western Precordillera occurred during Middle to Late Devonian, and Gosen (1997) described Devonian to preUpper Carboniferous contractional structures in the eastern Jáchal area. Astini et al. (1995), used stratigraphic and paleontological correlations to propose that the Precordillera started to collide with the western Gondwana margin during Early Ordovician times. The low greenschist facies metamorphism in the Western Allochthon was assigned a Late Silurian-Early Devonian age by correlation with rocks in the western Precordillera to the south (Gosen, 1997). In the southwestern Precordillera, the previous K-Ar dates and new ${ }^{40} \mathrm{Ar} /{ }^{39} \mathrm{Ar}$ dating lead Davis et al. (1999) to propose an Early to Middle Devonian age for the synmetamorphic top-to-the-east ductile deformation that juxtaposed pre-Carboniferous rock units. However, age correlations between the Western Allochthon and tectonic units to the south are uncertain until the structural relationship between both is established.

Our data along the Jáchal River area indicates a process of eastward emplacement of an eastpropagating thrust wedge that was completed before sedimentation of the Middle to Late Carboniferous Volcan Formation (Furque 1979; Furque et al. 1998). Some minor deformation at the frontal part of the thrust wedge could be slightly younger. In our section, the youngest sediments cut by the shear zone at the 
base of the Western Allochthon belong to the Early Devonian Talacasto Formation (Furque et al. 1998). We found no structural evidence for Ordovician age contractional deformation.

The data presented here raise questions regarding the tectonic context in which this Palaeozoic thrust wedge formed. Previously, the deformation of the Precordillera has been included within models of a long lasting process of terrain accretion related to east directed subduction (i.e. Ramos 1986, 1988; Astini et al. 1995). The main argument for east directed subduction was the west vergence of structures along the Jáchal River section and other areas of the Western Precordillera. At Cuesta del Viento, however, we suggest that the previously defined west vergent folds can be best interpreted as Z-shaped down facing minor folds on a larger east vergent structure. Furthermore, west vergent folds found in the central part of the section (Gosen 1997) can be interpreted as back rotated, east vergent folds with the rotation resulting from forward imbrication of thrusts and superposed Neogene faulting. In the Western Precordillera, south of our area, Davis et al. (1999) and Gerbi et al. (2002) also reinterpreted previously proposed Palaeozoic west vergent structures to have east vergence. Along the Jáchal River section, the internal distribution of strain within the thrust wedge, with stronger deformation in the west to lesser in the east, is also evidence for east directed emplacement. These geometries fit within a context of west directed subduction and underthrusting of a continental basement similar to thin-skinned thrust and fold belts in the external areas of other orogens. A Palaeozoic west directed subduction model has been proposed by Davis et al. (1999) and Gerbi et al. (2002) as the possible simplest tectonic scenario for emplacement of highly strained east-directed allochthonous units in the Western margin of the Precordillera. The same tectonic scenario was previously suggested by Astini et al. (1995) relying on the absence of volcanic or pyroclastic arc-derived rocks in the Precordillera.

\section{Neogene deformation}

The current interpretation of the Precordillera structure was that of a thin-skinned thrust belt (Allmendinger et al. 1990; Gosen 1992). This interpretation stems from the early recognition of an Ordovician carbonate layer that is repeated at the base of thrust plates in the central Precordillera (i.e. Baldis \& Chebli 1969). However, Carboniferous sediments unconformably cover the thrusts and folds developed in underlying Devonian sediments in the central part of the Jáchal River area, providing an unequivocal Paleozoic age, as was recognized by Furque (1979).

The Neogene structure of this part of the Precordillera is characterized by high-angle, NE striking, linked fault system. The linkage is apparent in the central and western part of the section, and widespread Quaternary sedimentation masks such connections in the east. The fault system appears to control the present distribution of basins and ranges, dividing them into rhomb shaped domains. Most faults have a component of oblique slip anf flower-type structures are interpreted at depth in the Iglesia, Tranca and Caracol basins based on several lines of evidence. These include, the structure within basin sediments, which does not resemble the structural style typically related to thin-skinned thrust systems, the coexistence of faults with reverse and normal throw, the change in dip orientation of faults and apparent vertical throw along strike. Recent studies also highlight the importance of strike-slip deformations in nearby areas (Introcaso \& Ruiz 2001). However, some Neogene basins appear to be bounded at their western margins by N-S striking thrusts (Allmendinger et al., 1990). Commonly, the sediments appear subvertical or even overturned due to dragging beneath the thrusts. Fault activity ranges from $20 \mathrm{Ma}$ to the present, including simultaneous motion and out of sequence thrusting (Jordan et al. 1993). 
Neogene deformation is superposed onto earlier Palaeozoic structures without substantially overprinting them. Neogene faults crosscut the earlier structures, and associated deformation partitioning causes rigid block rotations, local refolding and reactivation of some previous structures. These superposed deformations are thought to be responsible for the apparent western vergences of some Palaeozoic folds, and for differences in the strike of Palaeozoic structures between adjacent Neogene fault blocks. Open and non cylindrical folds that cause a curvature of Paleozoic surfaces (bedding and faults) and fold axes are locally found, suggesting some internal deformation of fault bounded blocks. Reactivation of previous anisotropy such as bedding or fault planes, and amplification of previous folds is also found.

The Neogene fault system appears to be deep rooted, yet caused less shortening than the 60-70\% previously proposed for the Jáchal river area (Allmendinger et al. 1990). Our section suggests shortening values in the order of 15 to $20 \%$ as indicated by the open folding in Neogene sediments and high angle of main faults. A detachment at $15 \mathrm{~km}$ depth was inferred from interpretations of depth to pre-Palaeozoic basement in seismic profiles in the Bermejo Foreland Basin and the Eastern Precordillera (Allmendinger et al. 1990; Zapata \& Allmendinger 1996a). However, the breaching fault system along the Jachal River area could merge at depth into a zone of distributed deformation rather than a discrete detachment surface, that may be explained by the existence of crustal seismicity beneath the Precordillera (Smalley et al. 1993; Pardo et al. 2000).

Neogene deformation in the Jáchal River area could fit within a model of transpressive deformation that caused net orogen longitudinal extension and net orogen perpendicular compression. As a result, several continental facies basins developed within the fault set. The N-S oriented right-lateral Tigre Fault that bounds the Precordillera along the Iglesia Calingasta Valley for more than $120 \mathrm{~km}$ (Siame et al. 1997) may be the major structure to which the transpressive fault system of the Jáchal River area is linked. This intracontinental Neogene to Present transpressional deformation may be connected to the kinematics and morphology of the subduction in this segment of the Andes (Brooks et al. 2003). In a review by Somoza (1998) of the available data relative to Nazca-South America relative motions, the convergence azimuths since $20 \mathrm{Ma}$ ago have been slightly oblique to the Chile Trench, including azimuth values between $82^{\circ}$ to $69^{\circ}$. The transpression may be governed by both the oblique subduction (DeMets et al. 1994; Somoza 1998) and the flat geometry of the subducting plate (Cahill \& Isacks 1992). Also, analogue and numerical modelling suggest that oblique convergence may be an important factor governing strain partitioning (Pinet \& Cobbold 1992; Chemenda et al. 2000). The oblique convergence combined with the increase of interplate coupling in flat subduction areas appear to enhance strain partitioning far inboard of the trench (Gutscher et al. 2000). This transpressive tectonic model for the foothills of the Andes makes this section of the Precordillera 'different' from other well-known models of thin-skinned deformation at foreland thrust belts. The lack of a flat lying, older sedimentary package ready to be transported and shortened above a general decollement level, also played an important role in the resulting deformation style.

\section{Conclusions}

Along a W-E cross-section of the complete Precordillera in the Jáchal River area, near $30^{\circ} \mathrm{S}$ latitude two major sets of structures reveal differing deformation styles that are superposed through time during the Palaeozoic to present tectonic evolution of this sector of the Andes. 
1) A pre-Upper Carboniferous E-verging thrust stack consisting of three main thrust units that exhibit important variation in structural style and stratigraphy, possibly due to large horizontal displacements. The thrust wedge includes at the rear the Western Allochthon which consists mostly of clastic Ordovician age rocks folded by large-scale asymmetric, E-verging folds with a well-developed axial planar cleavage and very low grade metamorphism. The Central Imbricate thrust system deforms mostly Siluro-Devonian rocks in a system of imbricate E-verging thrusts and associated fault propagation folds. The imbricate thrusts merge into a detachment near the base of the Ordovician carbonates. The Palaeozoic deformation in the Frontal Unit possibly consists of a protothrust structure at the core of an open anticline.

2) A Neogene set of steep transpressive faults that have uplifted and breached the previous thrust wedge. This Neogene fault system has a number of associated intramontane basins. On the basis of outcrop and seismic data, Neogene structures within most intramontane basins are interpreted to have flower-type geometries. It is common that within the Western Allochthon and Central Imbricate thrust system, the syntectonic sediments within the intramontane basins unconformably onlap onto the Palaeozoic at the basin margins. In some cases, reactivation of Palaeozoic thrust faults resulted in overthrusting of the basin sediments and in other cases progressive unconformities attest to the continuous uplift at the unconformable contact. Neogene overprinting of Palaeozoic structures produced backtilting and overturning of folds in the older thrust system.

\section{Acknowledgements}

This research was funded by the Spanish Ministry of Education and Culture, project PB98-1189, project BTE2002-04316-C03-01 and Grup de Qualitat de la Generalitat de

Catalunya, project 2001-SGR-00074. We thank T. R. Zapata (Repsol-YPF, Buenos Aires) for providing copies of seismic profiles. Insightful discussions on the structure of the Precordillera with V. Ramos are greatly appreciated. M. Carrión is thanked for his help and good times in the field. Journal reviews by J.

Kley and an anonymous reviewer are also thanked.

\section{References}

Alonso, J.L. 1989. Fold reactivation involving angular unconformable sequences: theoretical analysis and natural examples from the Cantabrian Zone (Northwest Spain), Tectonophysics, 170, 57-77.

Allmendinger, R. W., Figueroa, D., Snyder, D., Beer, J., Mpodozis, C. \& Isacks, B. L. 1990. Foreland shortening and crustal balancing in the Andes at 30 degrees S latitude, Tectonics, 9, 789-809.

Astini, R.A., Benedetto, J. L. \& Vaccari, N. E. 1995. The early Palaeozoic evolution of the Argentine Precordillera as a Laurentian rifted, drifted and collided terrane: A geodynamic model. GSA Bulletin, 107, 253-273.

Baldis, B.A.J. \& Chebli, G. 1969. Estructura profunda del área central de la Precordillera sanjuanina, $I V$ Jorn. Geol. Argent., 1, 47-66.

Beer, J. A., Allmendinger, R.W., Figueroa, D.E. \& Jordan, T.E. 1990. Seismic stratigraphy of a Neogene piggyback basin, Argentina, AAPG Bull., 74, 1183-1202.

Brooks, B.A., Samlley, R., Kendrik, E., Manceda, R., Lauría, E., Maturana, R. \& Araujo, M. 2003. Crustal motion in the Southern Andes $\left(26^{\circ}-36^{\circ}\right)$ : Do the Andes behave like a microplate?. G3, v. 4, no. 10. doi:10.1029/2003GC000505. 
Cahill, T. \& Isacks, B. L. 1992. Seismicity and the shape of the subducted Nazca plate. J. Geophys. Res., 97, 17503-17529.

Cardo, R. in press. Carta Geológica 3169-I Rodeo, escala 1:250.000. Instituto de Geología y Recursos Minerales, Subsecretaría de Mineria, SEGEMAR. Republica Argentina, 2003.

Chemenda, A., Lallemand, S. \& Bokun, A. 2000. Strain partitioning and interplate friction in oblique subduction zones: Constraints provided by physical modeling. J. Geophys. Res., 105, 5567-5582.

Dalziel, I.W.D. 1997. Neoproterozoic-Palaeozoic geography and tectonics: Review, hypothesis, environmental speculation, G. S. A. Bulletin, 109, 1, 16-42.

DeMets, C., Gordon, R.G., Angus, D.F. \& Stein, C. 1994. Effect of recent revisions to the geomagnetic reversal time scale on stimate of current plate motions, Geophys.Res. Lett, 21, 2191-2194.

Davis, J. S., Roeske, S. M., McClelland, W. C. \& Snee, L. W. 1999. Closing the ocean between the Precordillera terrane and Chilenia: Early Devonian ophiolite emplacement and deformation in the southwest Precordillera. In: Laurentia-Gondwana Connections before Pangea, Ramos V. A. \& Keppie J. D. (Eds.). Geol. Soc. Amer., Spec. Paper, 336, 115-138.

Furque G., 1979. Descripción geológica de la Hoja 18c, Jáchal, Provincia de San Juan. Carta GeológicoEconómica de la República Argentina, Escala 1:200.000. Servicio Geológico Nacional Boletín $\mathrm{n}^{\circ}$ 164. Buenos Aires.

Furque G., González P., y Caballé M. 1998. Hoja Geológica 3169-II San José de Jáchal, escala 1:250.000. Instituto de Geología y Recursos Minerales, Subsecretaría de Mineria, SEGEMAR. República Argentina.

Gerbi, C., Roeske, S. M. \& Davis. J. S. 2002. Geology and structural history of the southwest Precordillera margin, northern Mendoza Province, Argentina. Jour. South Am. Earth Sci., 14, 821-835.

Gontalez Bonorino, G. \& Gonzalez Bonorino, F. 1991. Precordillera de Cuyo y Cordillera Frontal en el Paleozoico temprano: terrenos "bajo sospecha" de ser autoctonos. Revista Geológica de Chile, 18(2), 97-107.

Gosen, W. von, 1992. Structural evolution of the Argentine Precordillera; the Rio San Juan section, Journal of Structural Geology, 14, 643-667.

Gosen W. von, 1997. Early Paleozoic and Andean structural evolution in the Rio Jáchal section of the Argentine Precordillera. Jour. South Am. Earth Sci., 10, 361-388.

Gutscher, M. A., Spakman, W., Bijwaard, H. \& Engdahl, E.R. 2000. Geodynamics of flat subduction: Seismicity and tomographyc constraints from the Andean margin. Tectonics, 19, 5, 814-833.

Introcaso, A., \& Ruiz, F. 2001. Geophysical indicators of Neogene strike-slip faulting in the DesaguaderoBermejo tectonic lineament (northwest Argentina), Jour. South Am. Earth Sci., 14, 655-663.

Jordan, T. E., Allmendinger, R. W., Damanti, J.F. \& Drake, R.E. 1993. Chronology of motion in a complete thrust belt; the Precordillera, 30-31 degrees S, Andes Mountains, Journal of Geology, 101, 135-156.

Kay, S. M., Maksaev, V., Moscoso, R., Mpodozis, C. \& Gordillo, C. E. 1988. Tertiary Andean magmatism in Chile and Argentina between 28 and $33^{\circ} \mathrm{S}$ : correlation of magmatism chemistry with a changing benioff zone. Jour. South Am. Earth Sci., 1, 21-38.

Keller, M. 1999. Argentine Precordillera, Sedimentary and Plate Tectonic History of a Laurentian Crustal Fragmente in South America. Geol. Soc. Amer., Spec. Paper, 341, 131pp. 
Pardo, M., Monfret, T. \& Comte, D. 2000. Sismotectónica y distribución de esfuerzos en la zona de subducciçon subhorizontal de Chile Central $\left(30^{\circ} \mathrm{S}-32^{\circ} \mathrm{S}\right)$, utilizando datos telesismicos. IX Congreso Geológico Chileno, Actas vol. 2, 459-463, Puerto Varas, Chile.

Pinet, N. \& Cobbold, P. R. 1992. Experimental insights into the partitioning of motion within zones of oblique subduction, Tectonophysics, 206, 371-388.

Ramos, V. A. 1988. The tectonics of the Central Andes; $30^{\circ}$ to $33^{\circ} \mathrm{S}$ latitude. In: Processes in Continental Litospheric Deformation, S. Clark \& D. Burchfiel (Eds.). Geol. Soc. Amer., Spec. Paper, 218, 31-54.

Ramos, V. A., Jordan, T. E., Allmendinger, R. W., Mpodozis, C., Kay, S. M., Cortés, J. M. \& Palma, M. 1986. Paleozoic Terranes of the Central Argentine-Chilean Andes. Tectonics, 5, 855-880.

Ramos, V. A., Cristallini, E. O. \& Pérez, D. J. 2002. The Pampean flat-slab of the Central Andes. Jour. South Am. Earth Sci., 15, 59-78.

Rapela C.W., Pankhurst, R.J., Casquet, C., Baldo, E., Saavedra, J. \& Galindo, C. 1998. Early evolution of the Proto-Andean margin of South America. Geology, 26, 707-710.

Siame L. L., Bourlès, D. L., Sébrier, M., Bellier, O., Castano, J. C., Araujo, M.; Perez, M., Raisbeck, G.M. \& Yiou, F. 1997. Cosmogenic dating ranging from 20 to $70 \mathrm{Ka}$ of a series of alluvial fan surfaces affected by the El Tigre Fault, Argentina. Geology, 25, 975-978.

Smalley, Jr. R., Pujol, J., Regnier, M., Chiu, J. M., Chatelain, J. L., Isacks, B. L., Araujo, M. \& Puebla, N. 1993. Basement seismicity beneath the Andean Precordillera thin-skinned thrust belt and implications for crustal and lithospheric behavior, Tectonics, 12, 1, 63-76.

Somoza, R. 1998. Updated (Farallon)-South America relative motions during the last 40 My: implications for mountain building in the central Andean region. Jour. South Am. Earth Sci., 11, 3, 211-215.

Sylvester, A. G. 1988. Strike-slip faults, Geol. Soc. Am. Bull., 100, 1666-1703.

Zapata, T. R. \& Allmendinger, R. W. 1996a. Growth stratal records of instantaneous and progressive limb rotation in the Precordillera thrust belt and Bermejo Basin, Argentina. Tectonics, 15, 1065-1083.

Zapata, T. R. \& Allmendinger, R. W. 1996b. Thrust-Front Zone of the Precordillera, Argentina: A thickskinned triangle Zone, A.A.P.G. Bulletin, 80, 3, 359-381.

\section{FIGURE CAPTIONS}

Fig. 1. A) Map of western South America illustrating the main provinces of the Andes between $29^{\circ}-33^{\circ} \mathrm{S}$ latitude, above a segment of shallow angle of subduction of the Nazca plate (contours of Wadati-Beniof zone in dash line from Cahill \& Isacks (1992)). The Principal Cordillera in Chile includes N-S trending low ranges and basins; the Frontal Cordillera includes the areas of highest topography, the Precordillera forms the foothills; the Sierras Pampeanas are ridges of basement that pop up within the foreland basin sediments. The large active basins that bound the Precordillera to the $\mathrm{W}$ and $\mathrm{E}$ are marked, the Iglesia-Calingasta Basin (a) and the Bermejo Basin (b). Box represents area of this study and location of maps in figure 2 and 3. Inset shows a portion of the Central and Southern Andes next to the Nazca plate that subducts slightly oblique ( $75^{\circ}$ azimuth) along the Chile Trench at $7.8 \mathrm{~cm} / \mathrm{yr}$ (DeMets et al. 1994).

Fig. 2. A) Geological sketch map of the Jáchal River area showing the distribution of Palaeozoic and Cenozoic strata and locations of detailed maps in other figures. Palaeozoic outcrops appear in the high topographic areas forming ridges and Cenozoic sediments occupy the lows. B) Simplified stratigraphy of several Cenozoic basins redrafted from Beer et al. (1990), Jordan et al. (1993), and Jordan et al. (2001). C) 
The stratigraphy for the Palaeozoic strata is presented in three columns corresponding to the Palaeozoic thrust units. In the Western Allochthon the synthetic column is modified from Astini et al. (1995) representing the four lithotectonic units described in the text. Unit 1 and 2 correspond to the mélange, Unit 3 and 4 correspond to the eastern and western parts of the allochthon. The stratigraphy for the Central Imbricate Thrust System is based on Furque et al. (1998), and in the Frontal Unit is based on Zapata \& Allmendinger (1996), and Furque et al. (1998) (see text for description of lithologies).

Fig. 3. Geological map of a $50 \mathrm{~km}$ wide strip of Precordillera along the Jáchal River area. Note the Jáchal River running along the central part. The main Neogene faults are in thicker lines and dashed when covered by Quaternary alluvial fans (faults marked as F1 to F8 for correlation with cross-section in figure 4). Palaeozoic thrusts are represented in thinner lines. Segments A, B and C indicate the location of geological cross-section (Fig. 4). Map is based on field mapping and 1:250,000 geological maps of Rodeo (Cardo, in press) and San José de Jáchal (Furque et al. 1998). Permian and Triassic rocks of Fiscal Basin are not differenciated.

Fig. 4. Composite geological cross-section of the Precordillera along the Jáchal River area. The section is based on detailed structural data taken along the outcrops near the road cut parallel to the Jáchal River (part A and B) and the road to Huaco (part C). Minor inconsistencies in dimensions between cross-section and map of figure $3 \mathrm{~B}$ are due to differences in projection between the satelite image used for drawing the map and the 100.000 scale topographic maps used for drawing the cross-section. The interpretation of seismic profile 5324 across the Iglesia basin is added in the west (see location of this profile in figure 5). The section shows a Palaeozoic east vergent thrust stack breached by high angle, Neogene faults that have associated basins (faults marked as F1 to F8 for correlation with map in figure 3). Interpretations at depth are constrained by geometrical criteria during cross-section construction other than balancing techniques due to lack of plane strain (see text for explanation).

Fig. 5. A) Map of the Neogene to Recent structures along the Rodeo deformation zone (location in figure 2A). White areas include Neogene and Quaternary undifferentiated sediments. Most of the area is covered by Quaternary alluvial fans, Miocene sediments appear mainly in the central part along the Iglesia River and minor outcrops along smaller subsidiary creeks. Lower Palaeozoic rocks are in grey. Box represents area amplified in B. B) Distribution of axial traces of noncylindrical folds that are oblique to the fault trace. Note that the axial traces of the anticlyne and syncline to the north converge and pass southwards to a single syncline trace. Sections 1 to 3 depicting high-angle faults and related folds. Progressive unconformities are common within the basin sediments (horizontal scale = vertical scale). C) Interpretation of seismic section across the Iglesia basin depicting flower type structures.

Fig. 6. A) Interpretation of seismic profile 5323 across de Iglesia Basin. The large-scale structure is dominated by flower-type geometries that include both west and East-dipping faults with normal and reverse apparent throw in two dimensions. Above fault A sediments thicken towards the fold crest. The flower-type structural style matches better with the type and distribution of structures observed at the 
surface (see figure 5 for location of the seismic profile). B) Enlarged piece of the seismic profile for better resolution of the structure of basin sediments above the flower structure.

Fig. 7. Detailed map and cross-sections along the Tranca valley (location of maps in figure 2A). Neogene sediments of this intramontane basin are partly covered along the valley centre by coarse Quaternary conglomerates associated with the actual stational Tranca stream that are not represented in the map. Three tectostratigraphic units differentiated in the Tranca basin are an older strongly red coloured package that could predate faulting, a middle pink-grey coloured coarse grained unit affected by faulting, and an upper grey coloured coarse grained unit that covers the fault although it drapes over it. Note the angular unconformities within syntectonic sediments in A and B thickening towards the fault.

Fig. 8. Detailed map and cross-sections along the Caracol valley (location of maps in figure 2A). Neogene sediments of this intramontane basin are partly covered along the valley centre by coarse Quaternary conglomerates associated with the actual stational Caracol stream that are not represented in the map. The cross-sections represent two tectonostratigraphic units separated by a basinwide unconformity, an older red coloured and an upper unit. These sedimentary packages are not correlated to the packages in the Tranca valley. F6 is marked for correlation with figures 3 and 4. Note contrasting apparent displacement on fault FX that appears in sections B, C and D. In all cross-sections horizontal scale is equal to vertical scale.

Fig. 9. A) Cross-section SW of San José de Jáchal that shows the Ordovician carbonates of the San Juan Formation in the frontal most thrust of the Central Imbricate thrust system ( $\mathrm{H}=\mathrm{V}$ scale). B) A piece of section across the Fiscal Basin is presented for comparison of the geometry of the Fiscal Thrust and distribution of Neogene sediments. Note the low angle unconformity at the base of Carboniferous sediments $(\mathrm{H}=\mathrm{V}$ scale). Large arrows are in Neogene faults and small arrows in Paleozoic thrusts. See Fig. 3 for location of cross-section line.

Fig. 10. A) Geological map of the area north of San José de Jáchal shown dip angles that document the unconformable relation of Carboniferous sediments (dotted pattern) above the Devonian sediments (grey fill). B) Cross-section NW of San José de Jáchal where the thrusting of the Western Allochthon mélange onto the Central Imbricate thrust system is not obscured by Neogene faulting, and includes the unconformable Carboniferous sediments onto the Central Imbricate thrust system (location in figure 3). The interpreted thrust in the east, beneath the unconformity, is interpreted to correspond to the northward prolongation of the frontal most thrust of the Central Imbricate thrust system that appears in the section of figure 4. C) Stereoplot of curved fold axes within the shear zone (C.I., contour interval; C.A., contouring area).

Fig. 11. A) Detailed cross-section of the Western Allochthon at Cuesta del Viento (Unit 4 in figure 2) and stereoplot of minor structures. The fault between the pillow lavas and the sediments deformed by meter scale down facing folds is interpreted to obliterate the core of a large antiform (see text for interpretation of way up in this part of the section). The thrusts within the Ordovician rocks are interpreted as Palaeozoic 
structures, because they do not seem to cut the contact with Neogene sediments to the north (see map in figure 3). Reactivations by Neogene age deformation cannot be ruled out and may have caused the open folding of that contact (see also figure 5A). B) Detailed cross-section of the Western Allochthon at Los Tuneles and stereoplot of minor structures. Units 1 and 2 consitute a tectonic melange and Unit 3 the frontal part of the allochthon. The thrusts mapped within the Ordovician rocks are interpreted as Palaeozoic structures. C) Stereoplot of fold axis within the Central Imbricate thrust system along section in figure 4. Changes in the orientation of structures between stereoplots along the Jáchal River area cross-section are interpreted mostly as due to overprinting caused by superimposed Neogene deformation. S0, bedding; S1, axial planar cleavage; S2, local crenulation cleavage; L1, intersection lineation.

Fig. 12. Idealized structure of the Palaeozoic thrust wedge during Carboniferous times.

Deformation style in the western part (Western Allochthon) includes tight folding with associated axial planar cleavage and slight metamorphism. Imbricate thrusts and fold propagation folding appears in the east (Central Imbricate thrust system) and shortening dies out at a protothrust (Frontal Unit). In this interpretation the mélange corresponds to the sole of the Western Allochthon (tectonic mélange) that could be prolonged further beneath its basal thrust. Later Neogene deformation and breaching faults caused juxtaposition of pieces of the Palaeozoic thrust wedge that were laterally and vertically apart. This implies that the units, dimensions, and geometries displayed in this idealized thrust wedge could vary greatly from those in a non-disturbed, originally continuous E-W Palaeozoic section. 




Fig. 1. Alvarez-Marron et al. 
A



B


DPre-Neogene strata

\section{Tranca Basin Caracol Basin}
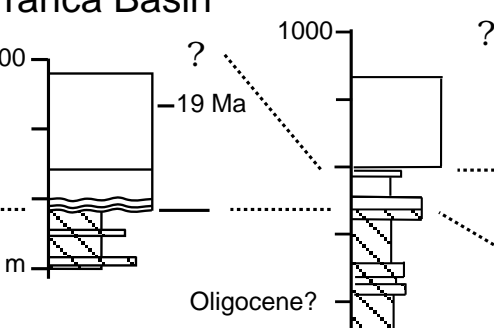

$0 \mathrm{~m}$

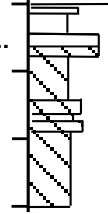

Fiscal Basin

\section{Fisca}

3

Central Imbricate Thrust System

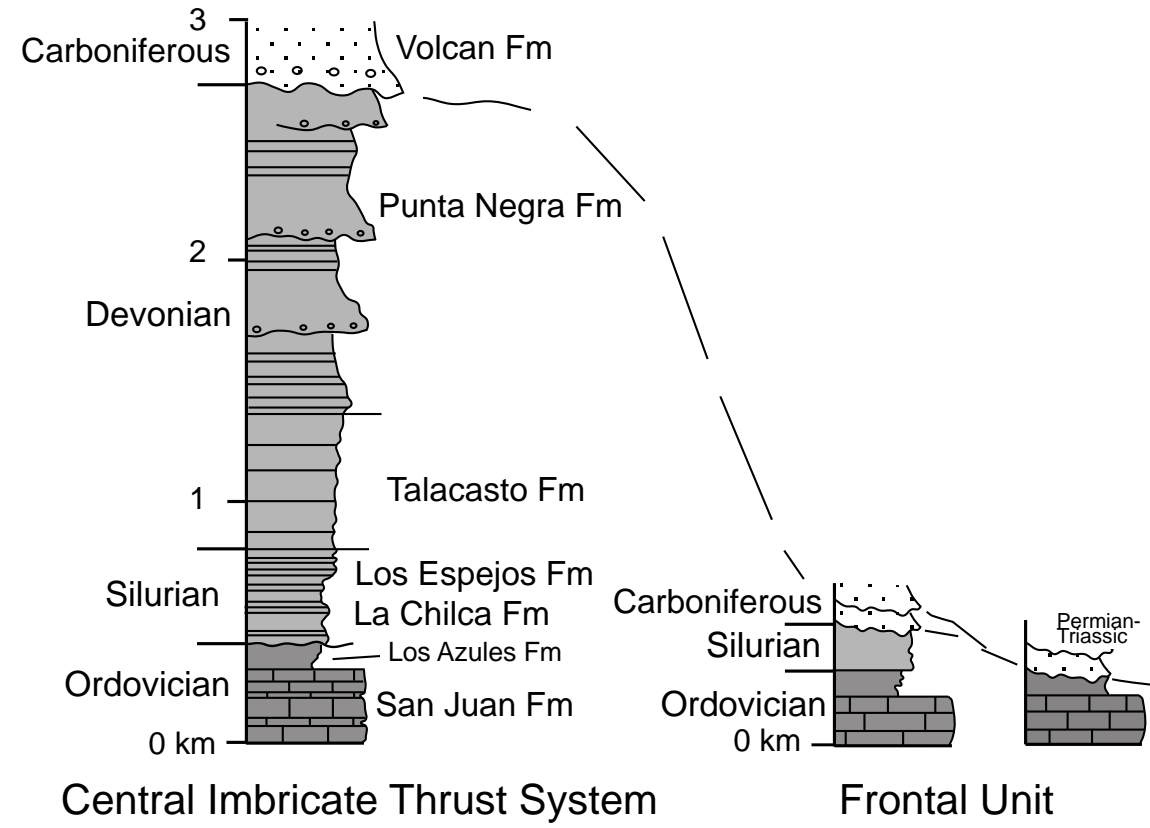



Bermejo Basin

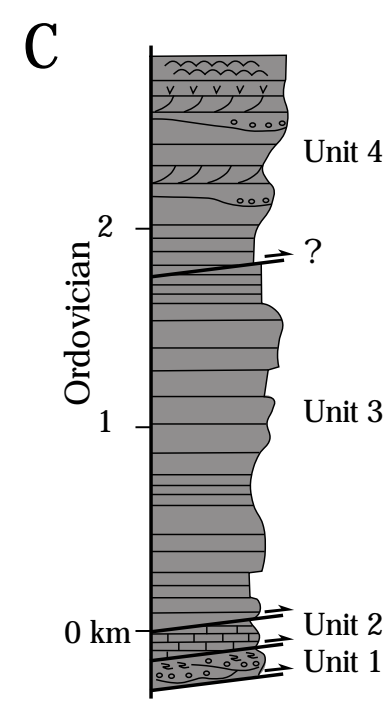

Western Allochthon

Figure 2. Alvarez-Marron et al. 


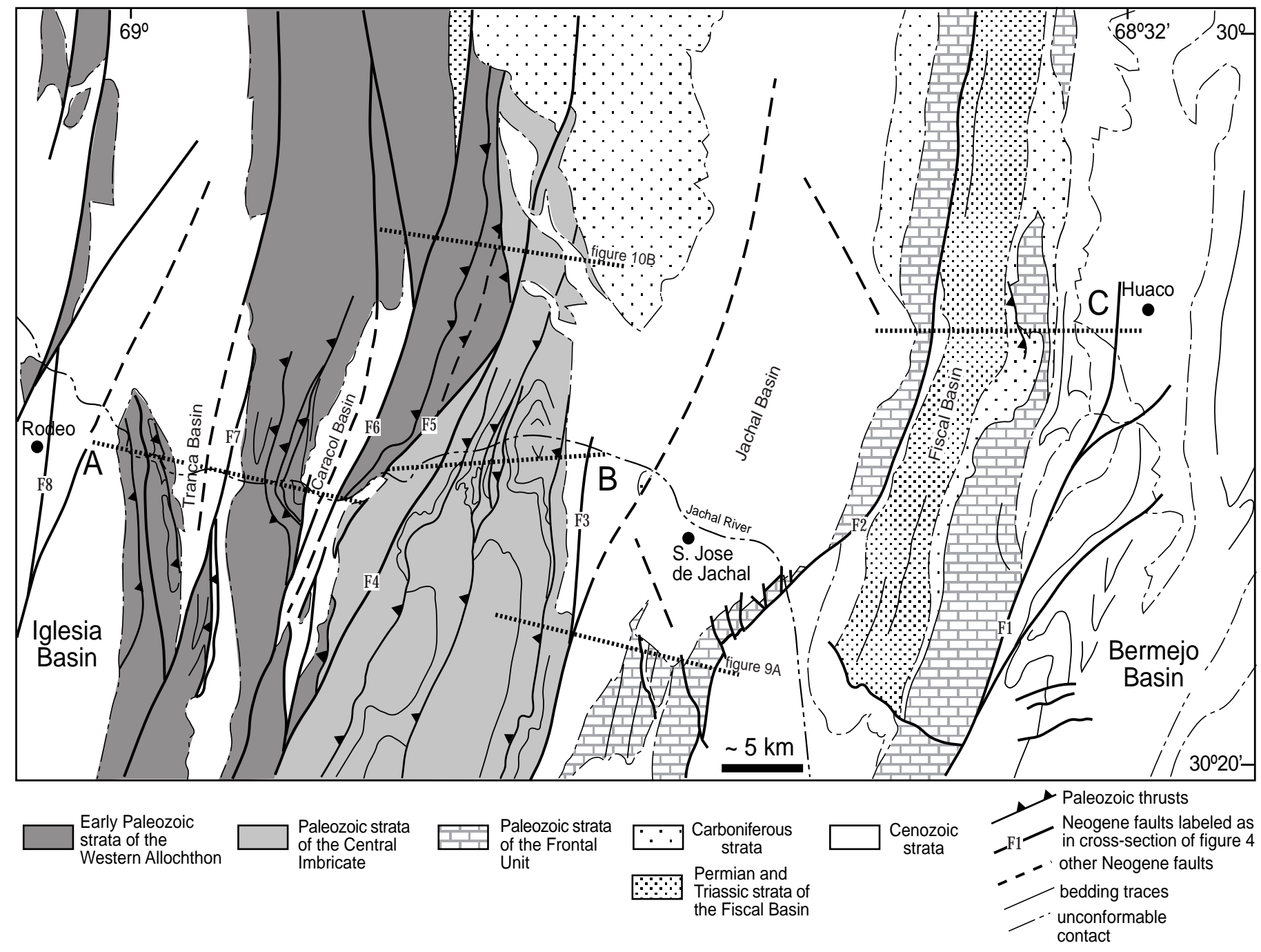

Fig. 3. Alvarez-Marron et al. 




Fig. 4 Alvarez-Marron et al. 



* syncline axial trace $85 y$ Fault dip $\uparrow$ anticline axial trace $\nmid 20$ Bedding dip
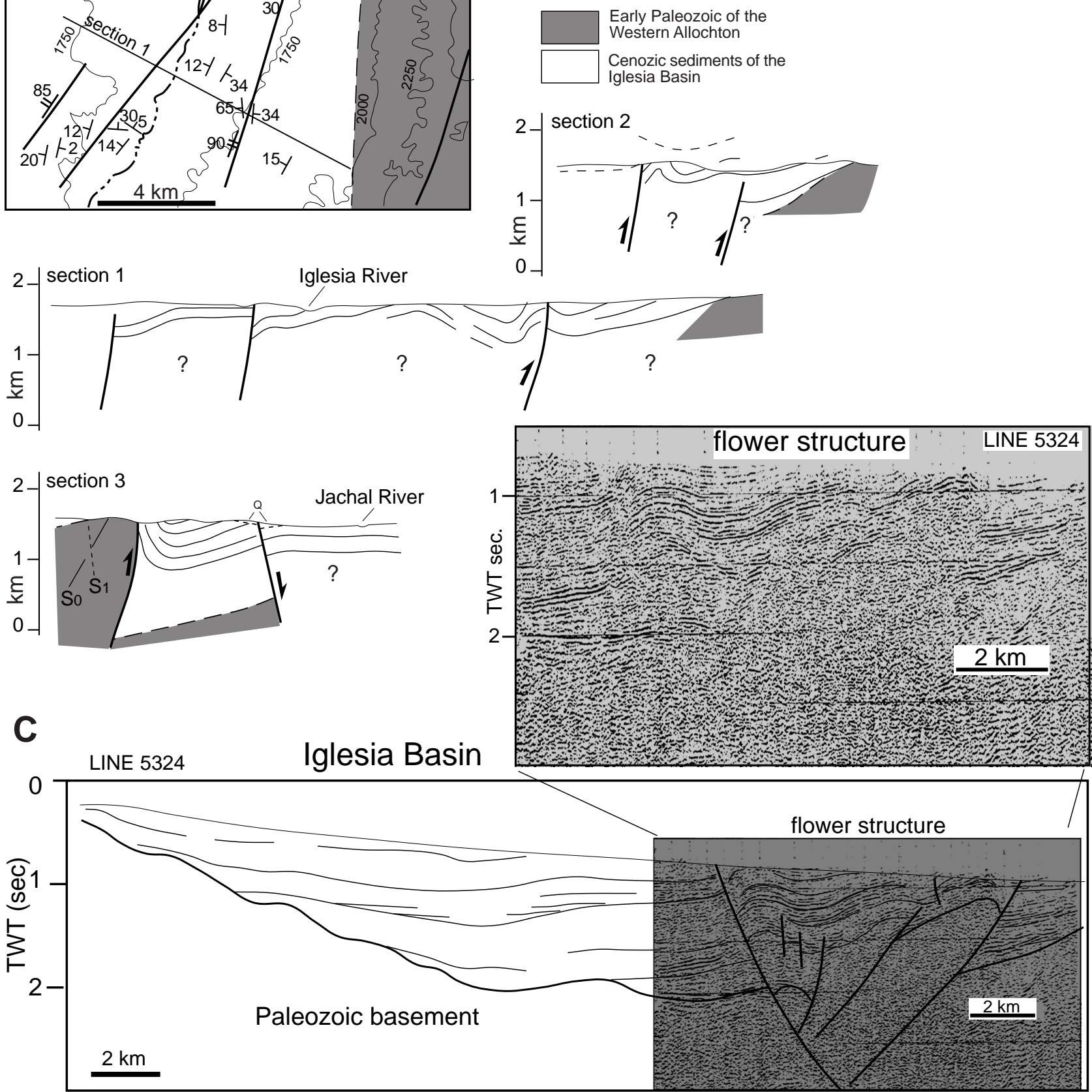

Figura 5. Alvarez-Marron et al. 


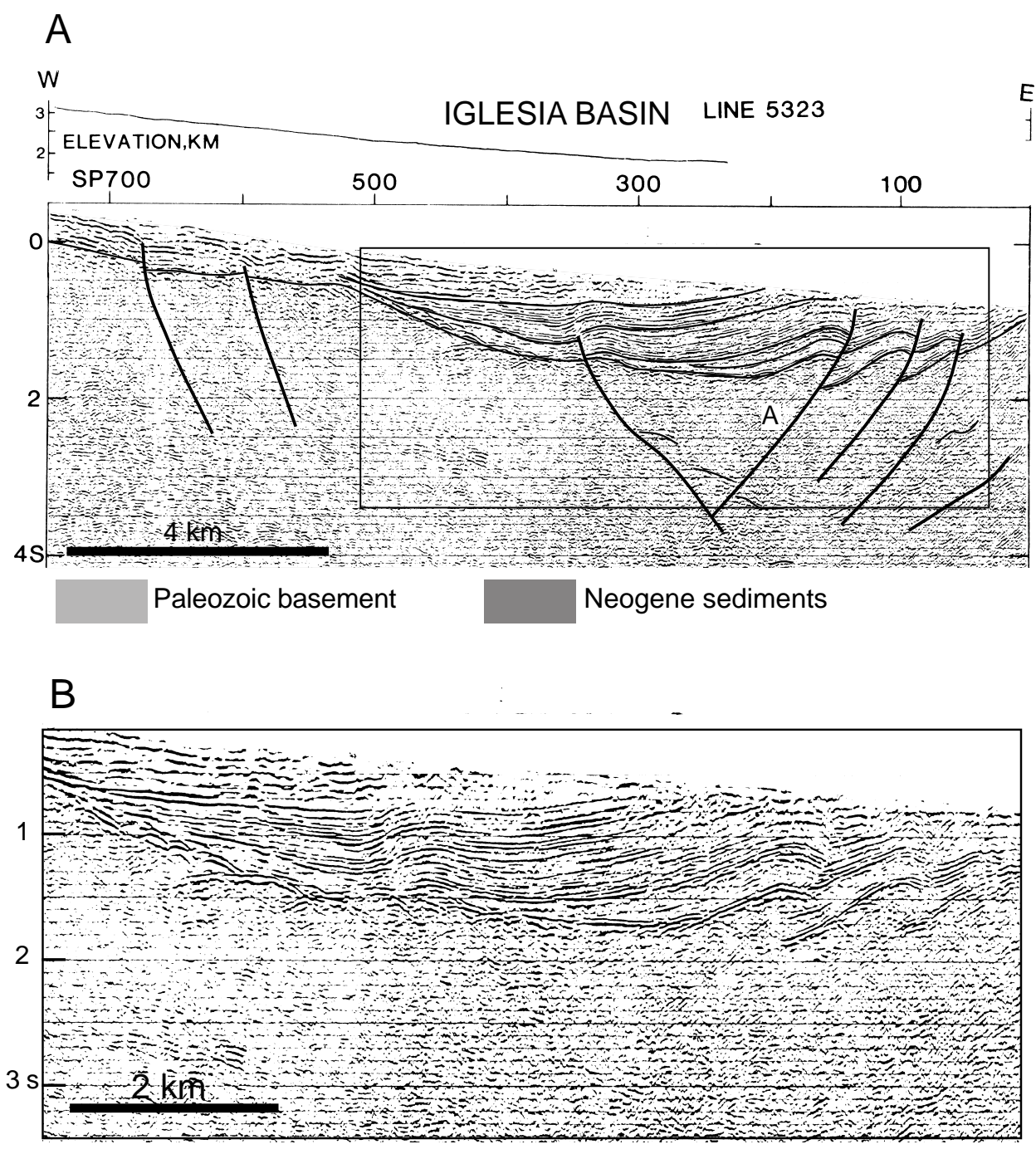

Figure 6. Alvarez-Marron et al. 


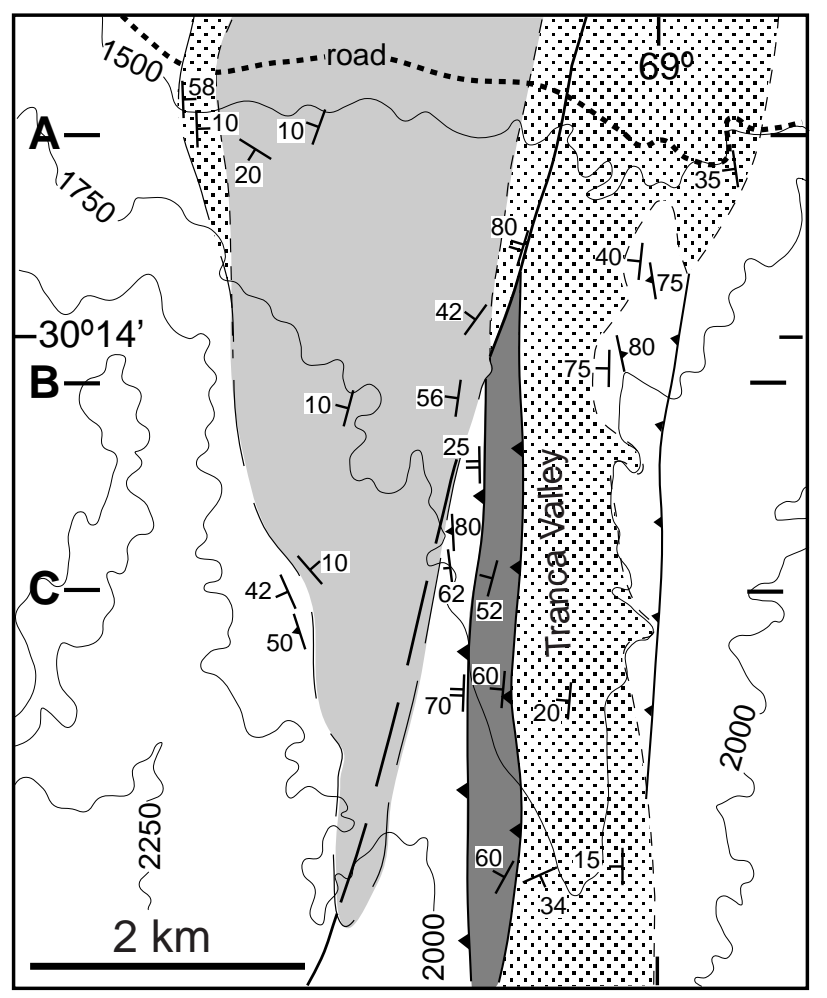

$15 y$ dip angle bedding

50 f dip angle cleavage

80 y dip angle Neogene fault
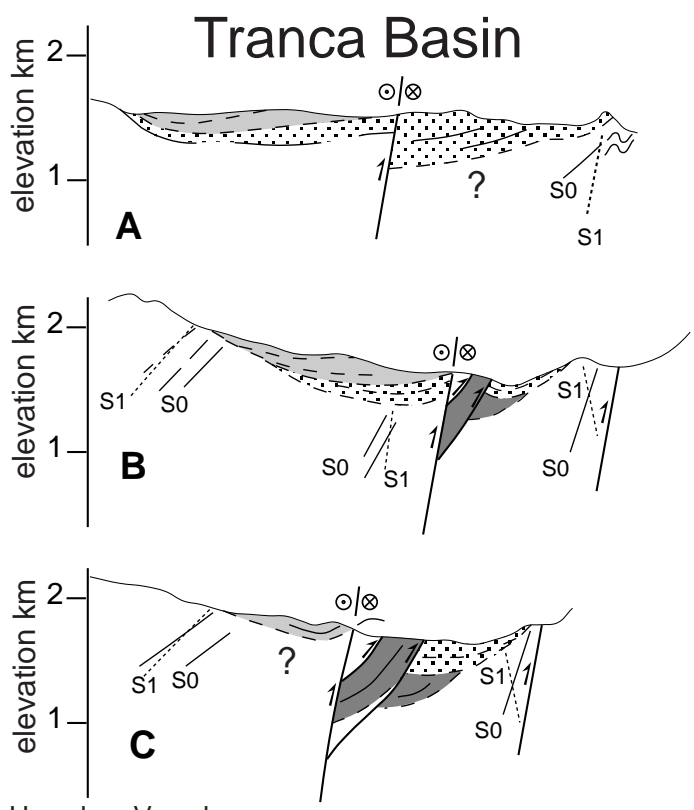

$\mathrm{H}$ scale $=\mathrm{V}$ scale

Ordovician rocks, Western Allochthon Cenozoic:

upper unit, sediments drape over fault middle unit, sediments cut by faults older red colored unit 


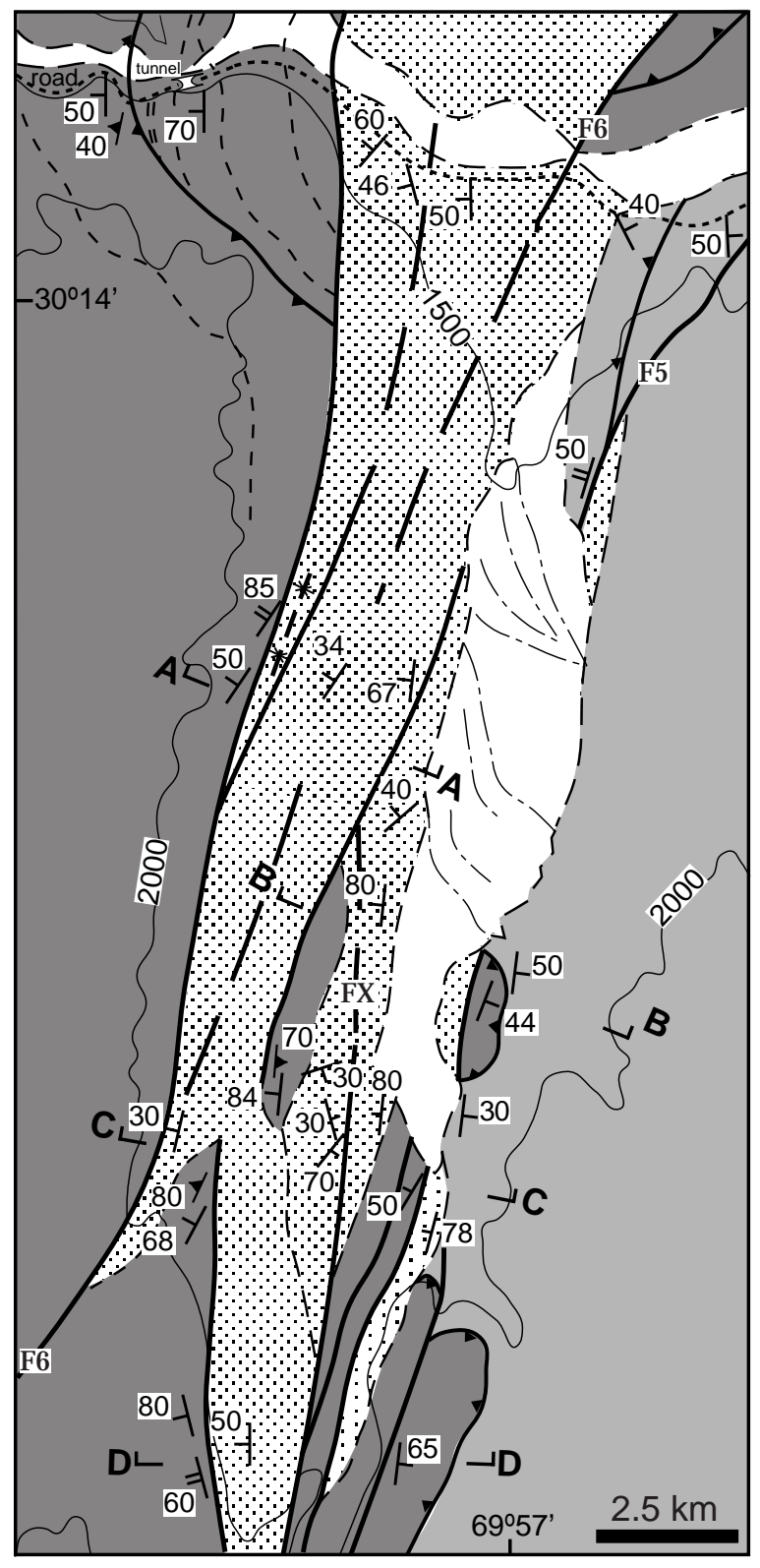

Quaternary sediments

: Tertiary rocks, Caracol Basin

Sil.-Dev. rocks, Central Imbricate T. S. Ordovician rocks, Western Allochthon
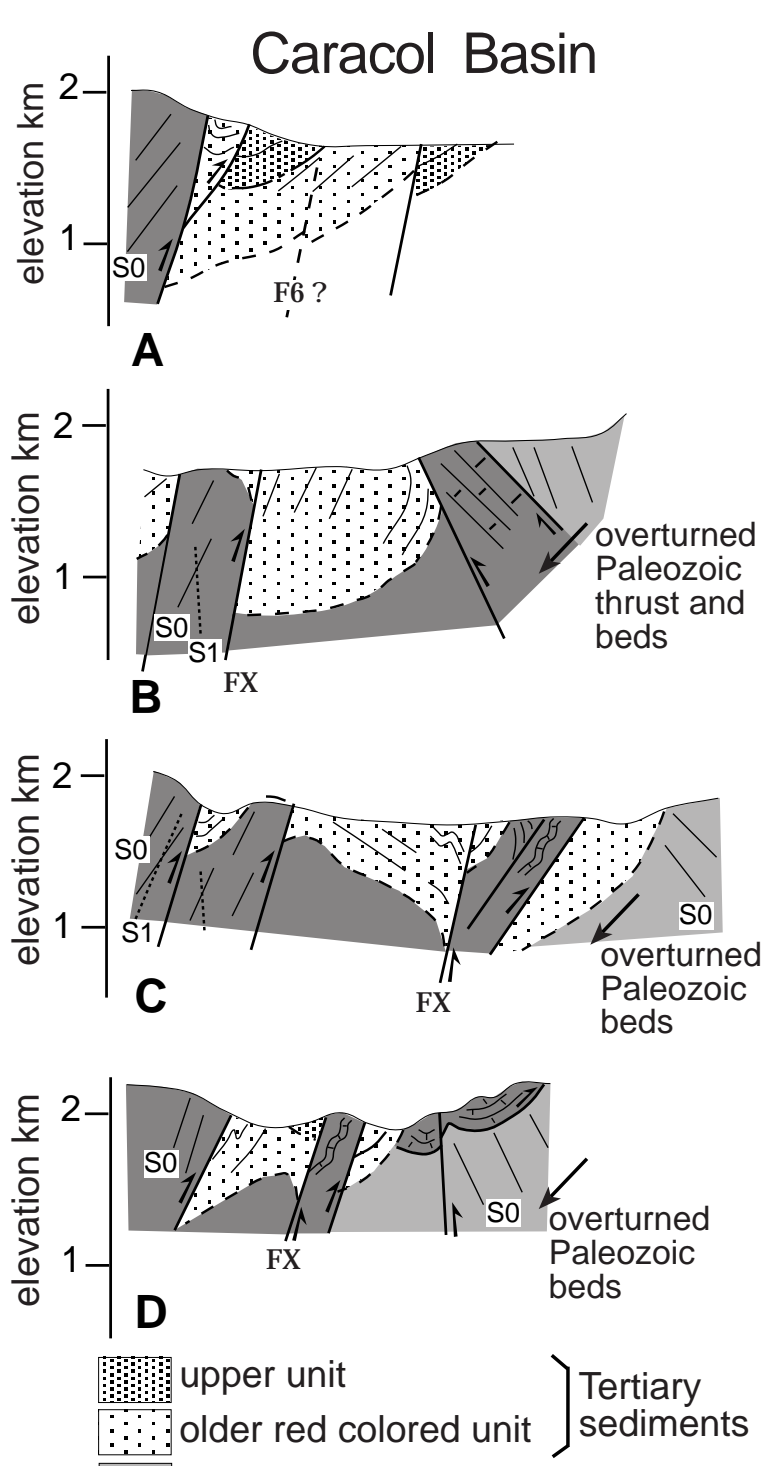

Sil.-Dev. rocks, Central Imbricate T. S. Ordovician rocks, Western Allochthon

Paleozoic thrust

15y dip angle bedding

50 f dip angle cleavage

$60 y$ dip angle Neogene fault

Figure 8. Alvarez-Marron et al. 
A

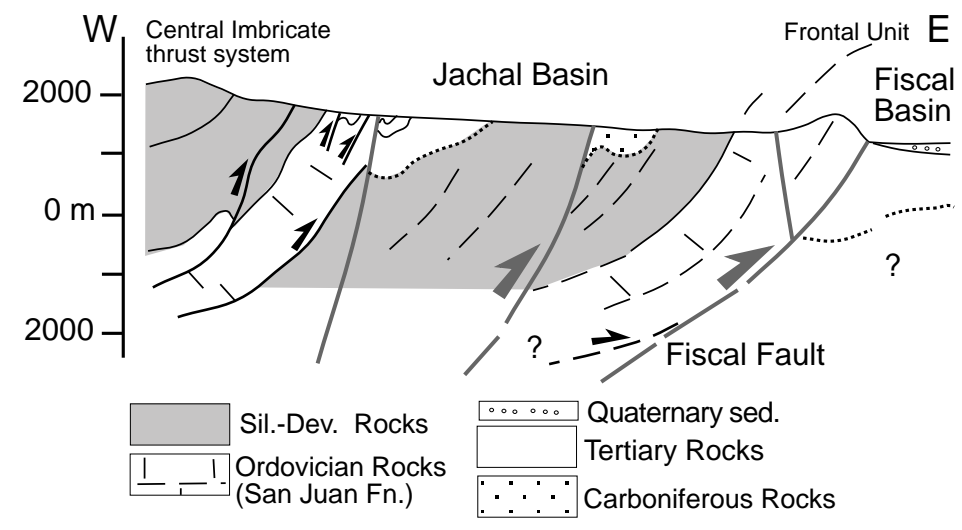

B

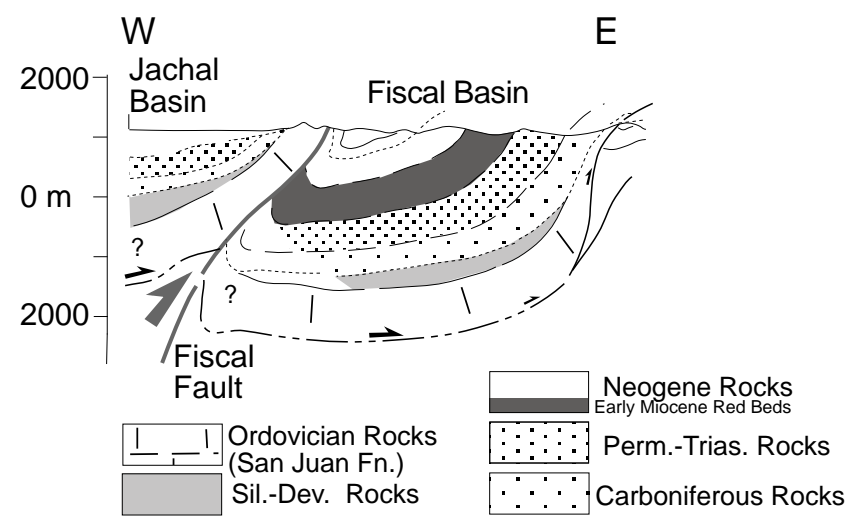

Figure 9. Alvarez-Marron et al. 

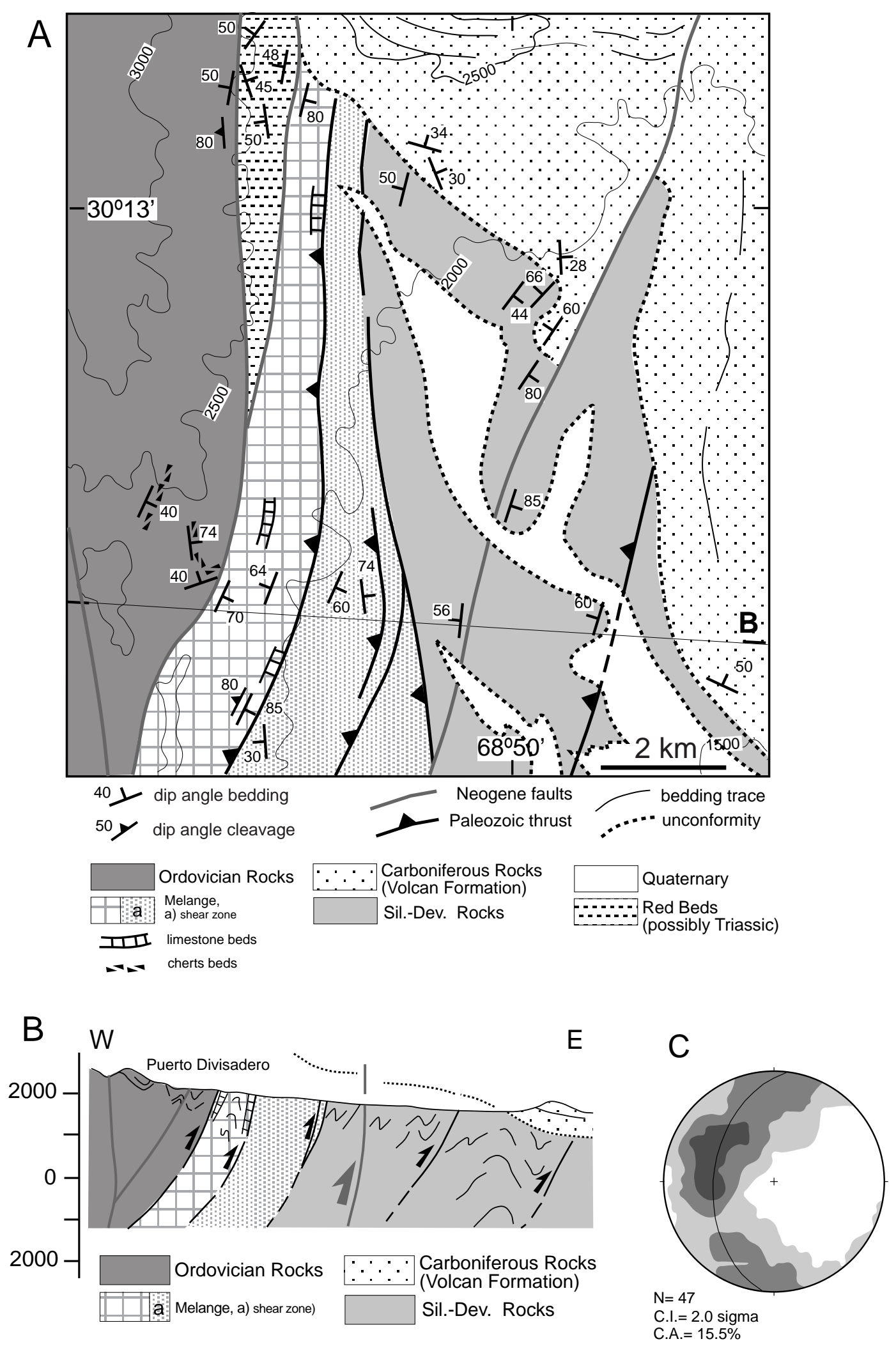

Figure 10. Alvarez-Marron et al. 

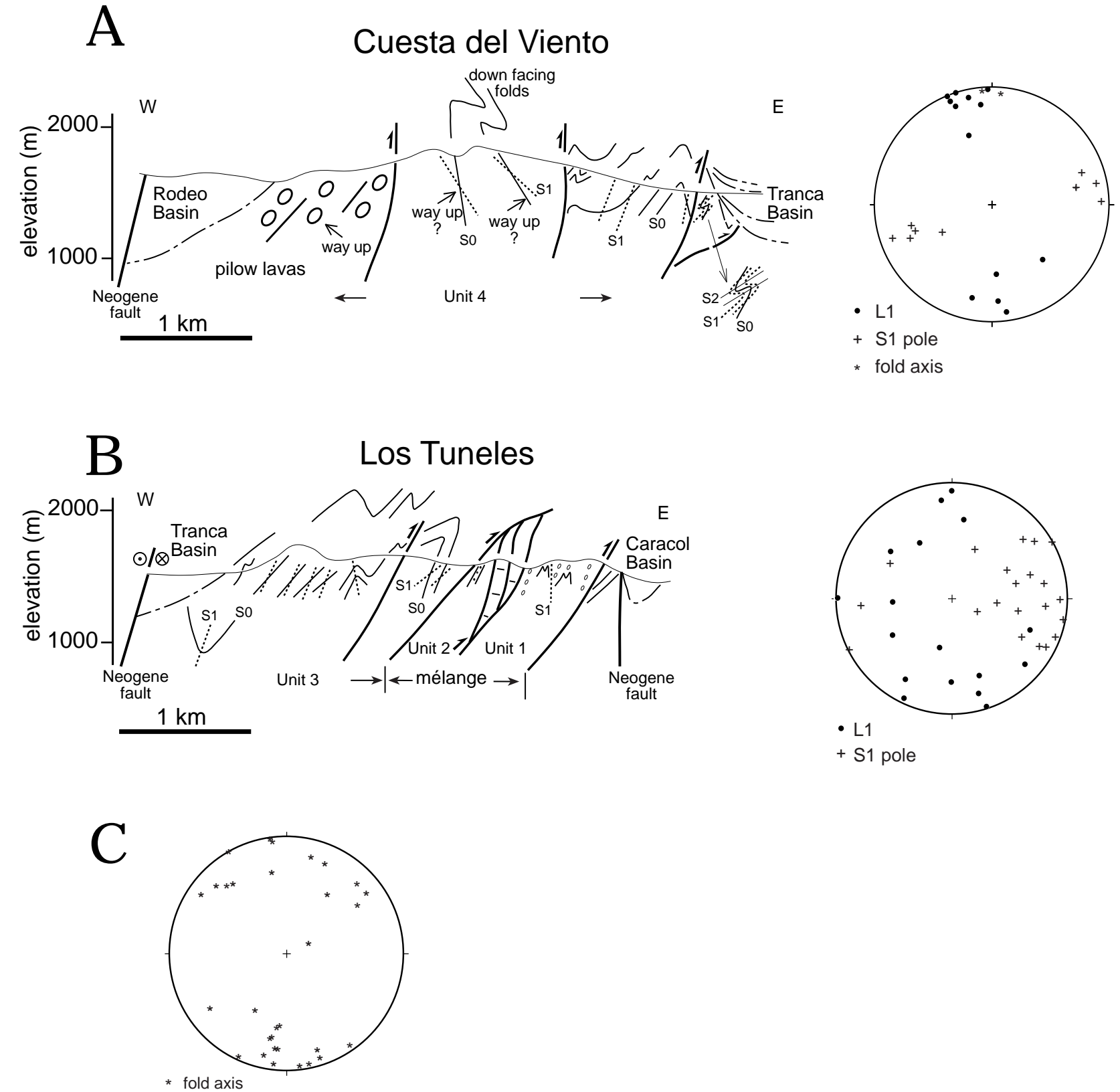

Central Imbricate

Figure 11. Alvarez-Marron et al. 


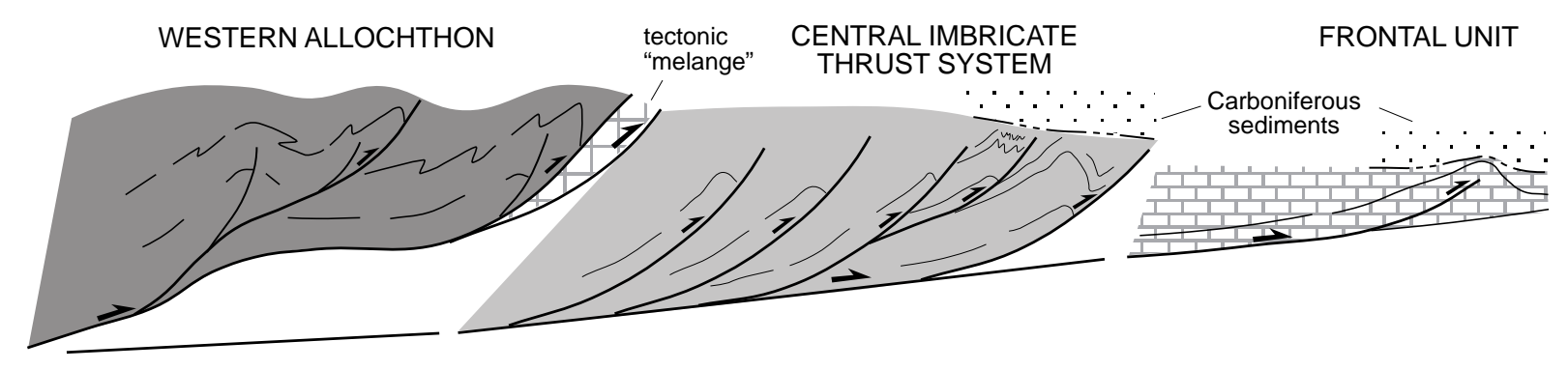

Figure 12. Alvarez-Marron et al. 